\title{
Carian 'portraiture' and Coan coinage in the fourth century BCE
}

\author{
Håkon Roland
}

\begin{abstract}
The point of departure of this article is the alleged iconographic connection between major fourth-century BCE Coan coin issues and the Hecatomnid sculptures of the Mausoleum in Halicarnassus. The historical setting is Caria in the first half of the fourth century BCE. The most decisive year in Coan history was 366 BCE. This was the year of the synoecism, when the different settlements on the island were gathered into one common political unit, an incident most often associated with a 'democratic' movement. The synoecism entailed a relocation of the capital to the easternmost part of the island, the point closest to the mainland of Asia Minor and the capital of the Hecatomnid dynasty. The Coan coin issues in question are used by bistorians as (the only) evidence for an early interference by Hecatomnid rulers on Cos and, based on this, to consider Mausolus bimself as a driving force behind the synoecism on Cos in 366 BCE. The idea of the Hecatomnids as rulers of a more or less 'Carian kingdom' has gained support over the years, while pointing to Mausolus as the primus motor in establishing the polis of Cos fits the picture well. If so, the synoecism on Cos would have been caused by 'oligarchic' forces. Alleged evidence is provided by Coan coinage with Heracles and Demeter renderings, and a supposed iconographic likeness between these deities on coinage and portrait sculptures of the Mausoleum in Halicarnassus.
\end{abstract}

KEYWORDS: Caria, coinage, Cos, Halicarnassus, Mausoleum, Mausolus, Orientalism, portraiture

This article investigates the alleged connection between the Hecatomnid rulers of Halicarnassus and Heracles and Demeter renderings on Coan fourth-century BCE coinage. ${ }^{1 *}$ There are no historical or archaeological sources attesting Hecatomnid influence on the island of Cos in the 370 s and $360 \mathrm{~s}^{2}$, which explains why identifying Carian portraits on Coan coins of this period matters. If such portraits are verified it would constitute the only evidence of Hecatomnid influence on Cos in this formative period of the history of the island.

* According to the CLARA guidelines, footnotes should be concise and state author, year and pages only, and if necessary, a brief explanatory note. The present article deviates from this style because of the level of detail needed for the argumentation.

${ }^{1}$ Konuk 1998; Sherwin-White 1978; Hill 1923; Svoronos 1904-1908; Six 1899; Weber 1892. The connection between the statue group from the Mausoleum in Halicarnassus and Coan coins with Heracles and Demeter was briefly criticized in Ingvaldsen (Roland) 2011.

2 All dates are BCE unless otherwise stated. 


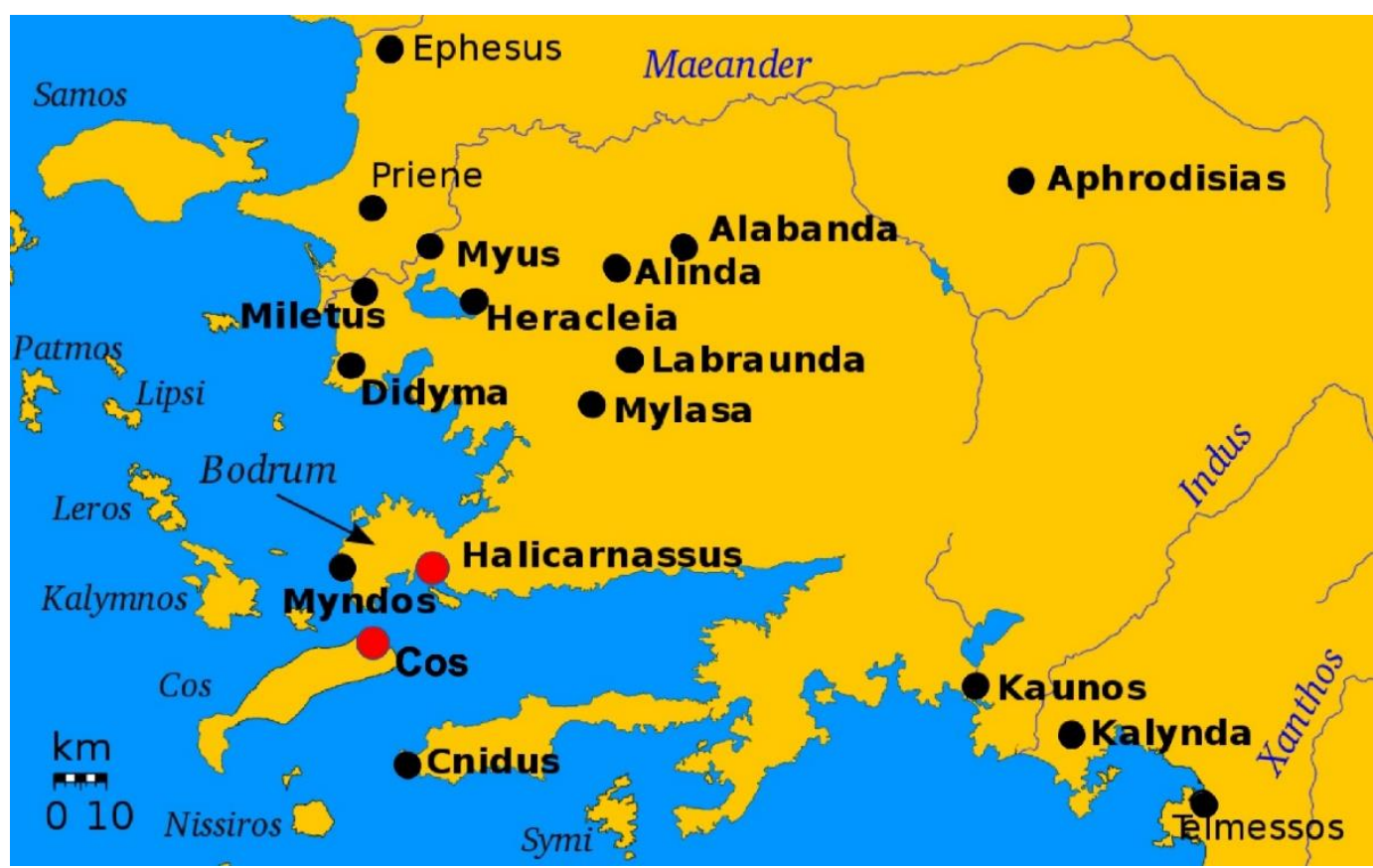

Fig. 1 Map of ancient Caria showing cities. CC-BY-SA 3.0. Modified by H. Roland.

The article will first present a re-examination of the empirical evidence and a survey of the coinage and portraits in question. It then turns to a discussion of the possible explanations for why historians have embraced the hypothesis of Carian rulers appearing on a city-state coinage without empirical evidence. The discussion aims to examine to what extent unconscious biases and associations rooted in modern concepts of e.g. 'Orientalism' have led to wrong conclusions, and based on this case study to further emphasize the importance of self-reflexive approaches to avoid bad theories put forward on uncertain evidence, or in the worst case, to let the interpretation of objects from the crossroads between Eastern satrapies and Greek poleis be unconsciously influenced by something reminiscent of 'Eurocentrism'. ${ }^{3}$

\section{The historical setting of Halicarnassus and Cos}

The island of Cos is situated close to the western coastline of modern Turkey (Fig. 1). The island's geographical location entailed that shifting alliances between Rhodes, Athens, Halicarnassus, Egypt and occasionally other Hellenistic rulers strongly affected the political and economic life on Cos. ${ }^{4}$

The synoecisms of Halicarnassus in 377 and Cos in 366 had a strong impact on the iconography of coinage and building programmes of both cities. ${ }^{5}$ The Coan capital

${ }^{3}$ Horden \& Purcell 2000, 533-535, 543.

4 Sherwin-White 1978 is still the most comprehensive historical survey.

5 Ingvaldsen (Roland) 2002, 28; Höghammar 1993, 34; Kabus-Preishofen 1989, 18; Hornblower 1982, 104; Sherwin-White 1978, 40-45; Diodorus 15.76. 
was moved to a new location in the easternmost part of the island, the point closest to the mainland of Asia Minor and Halicarnassus. ${ }^{6}$ The synoecism was also the starting point of the large coin issues relevant to the discussion below. Mausolus came to power in 377/6, and the Carian capital was moved from Mylasa to Halicarnassus in the following decade. Diodorus describes Halicarnassus as 'the heart and capital of Caria' in 362, which implies that Mausolus' large-scale building programme, including the sculptures under discussion here, had progressed significantly by that year. However, no sources confirm any Hecatomnid influence on Cos at the time of the synoecism, even though an alliance is attested in 357. General contact is also attested archaeologically, e.g. by similarities in city plan in the two new capitals ${ }^{8}$, and the use of Coan marble and limestone for the famous Mausoleum. ${ }^{9}$

\section{Carian portraiture and Coan coinage}

The following discussion is centred around the major fourth-century issues of large silver coins from Cos. A large output of Rhodian weight silver coins followed the Coan synoecism in 366. The Doric hero Heracles graced this first large-scale coinage of Cos, even though the first Heracles-issues were introduced in the 390s, almost three decades before the synoecism. The Coan parasemon, a saltwater crab, was put on the reverse. For a time, a veiled female head replaced the crab. A combination of the heads of two deities on the obverse and reverse respectively is rarely seen in Greek coinage of this period. It is in these issues that scholars have claimed to see a resemblance between the Heracles head and a colossal statue from the Mausoleum in Halicarnassus - the so-called Mausolus ${ }^{10}$ (Fig. 2). And, following this, scholars have also interpreted the features of Mausolus' sister-wife Artemisia (who continued to reign until her death in 351) in the draped female head on the reverse of some of the issues. However, since the female head undeniably falls into two separate stylistic groups, they cannot possibly represent the same individual. Historians solved this problem by identifying one as Artemisia, and the other as the Ptolemaic Egyptian Queen Berenice I (fl. $317-$ 275).

The line of arguments presented in this article requires a thorough review of the Heracles and Demeter motif on Coan coinage, as well as the attempts to identify them as Hecatomnid rulers. The most important deity from a numismatic point of view is

\footnotetext{
${ }^{6}$ See Hansen 1995b: 58 for different types of synoecisms, the Coan belonging to his second type. For a definition of the ancient concept of polis, see Anderson 1983; Manville 1990, 53; FlenstedJensen 1995; Hansen 1995a; Flensted-Jensen \& Hansen 1996; Nielsen 1996, especially 13-16, 18 20

${ }^{7}$ Diodorus 15.90.3.

8 Pedersen 1989, 9.

${ }^{9}$ Stampolidis 1989, 48-49; Luttrell 1986, 203; Jeppesen 1958, 16-17.

${ }^{10}$ Richter 1965, 161-162; Bieber 1955, 71-72.
} 


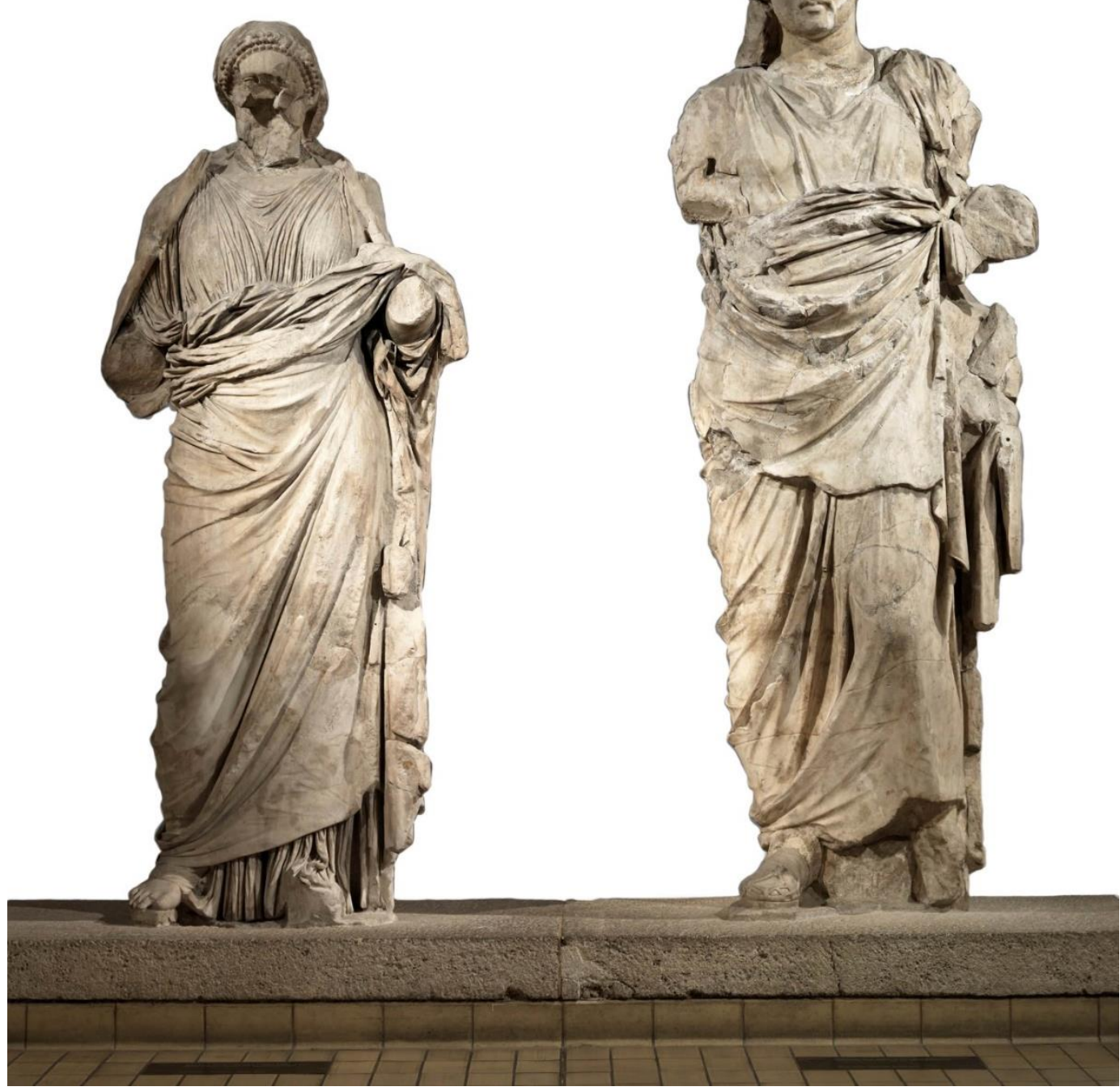

Fig. 2 The statue group of the so-called Mausolus and 'Artemisia' from the Mausoleum in Halicarnassus. Photograph: (C) British Museum, used by permission.

Heracles. He was chosen as the obverse motif on the first tetradrachm issue, and in total 21 of the 26 recorded issues of Coan coinage before $c .170$ display the image of this deity. ${ }^{11}$ The connections between Cos and Heracles and Demeter have a common point of origin in the myth of Erysichthon. The myth is partly described by Hesiod, in the Iliad, by Callimachus in the Hymn to Delos and by Theocritus in IdyllVII (supplied

11 Ingvaldsen (Roland) 2002. See also Stefanaki 2012. 


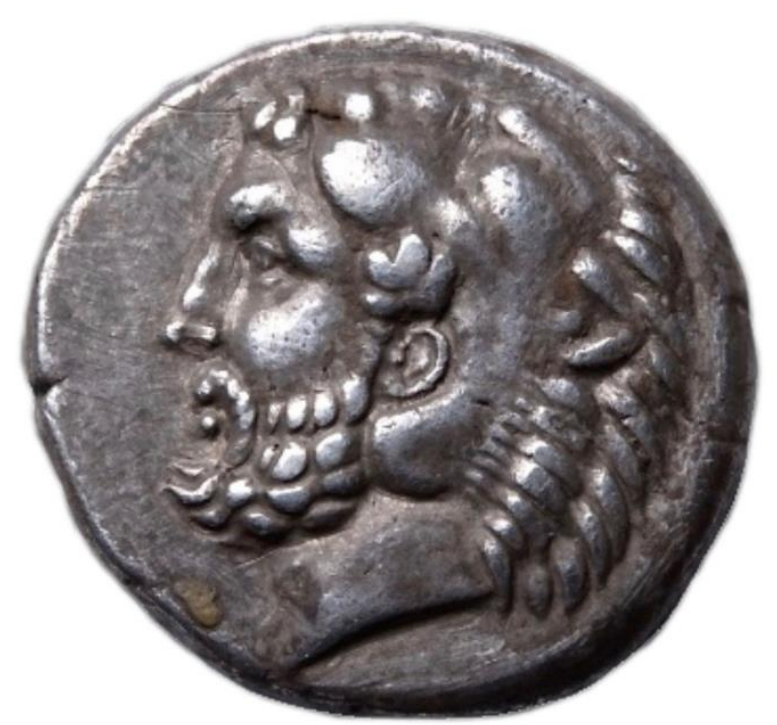

Fig. 3 Coan tetradrachm with Heracles head, c. 350 BCE.

Photograph: (C) Classical Numismatic Group LLC.

by the scholiast). ${ }^{12}$ Plutarch tells us that Heracles landed on Cos after the Trojan Wars. ${ }^{13}$ The ancient connection between Heracles and Cos in the myths is mirrored in the popularity and extent of the cult on the island in the fourth- and third centuries. Heracles is attested as tutelary deity of the gymnasium together with Apollo. A regular festival, Herakleia, is attested, as is the existence of a Herakleion, a public cult of Heracles as Kallinikos and local cults at Halasarna, Phyxa and Antimachia.

The cult of Demeter was also important on Cos, and a small, archaic sanctuary of Demeter and Kore is one of the oldest attested cults on Cos. The sanctuary belongs to an early fourth-century context and attests the cult of Demeter in a period before the synoecism. ${ }^{14}$ The cult kept its strong position on Cos throughout the Hellenistic period with several local shrines located in the different demes, such as a small sanctuary at Kyparissi in the deme of the Halentioi and another in the deme of Hippia. Callimachus and Theocritus describe several festivals in the name of Demeter. Demeter had a strong position early in the fourth century, and is a likely candidate for a reverse motif, supplementing Heracles, on Coan coinage of the mid-fourth century. The draped female head on three contemporary, important silver issues and a later issue of bronze coins is identified as Demeter solely because of her importance in the religious life of Cos. It is likely that the draped female head on the silver issues and

\footnotetext{
${ }^{12}$ References from Sherwin-White 1978, 306-307, nos. 148, 149, 153, 154.

13 Plutarch, QG 58.

14 Sherwin-White 1978, 53, 305; Herzog 1901, 134-136.
} 


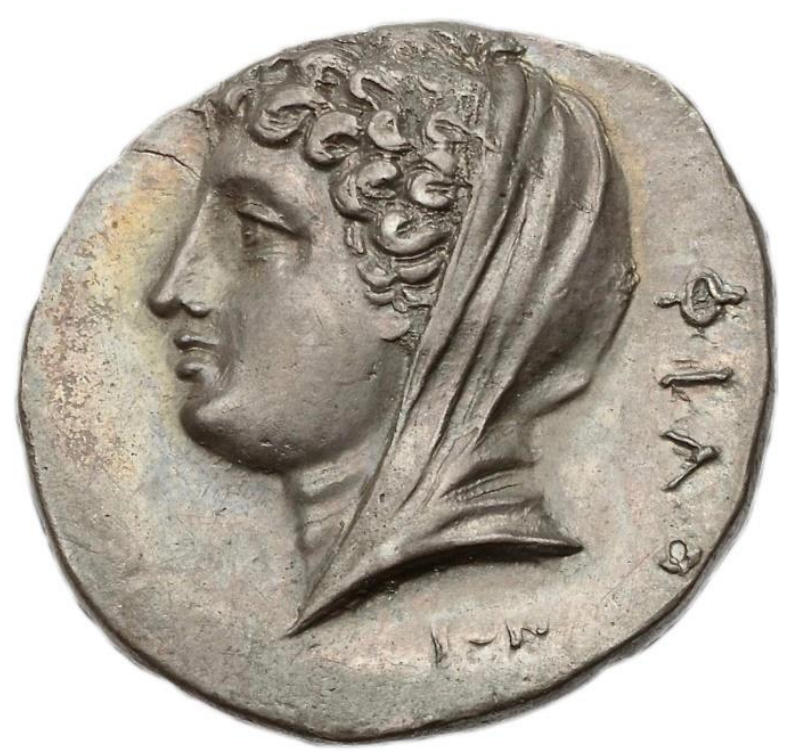

Fig. 4 Coan didrachm with female head, c. 345 BCE.

Photograph: (C) Classical Numismatic Group LLC.

the much later bronze issue represent the same deity because of the identical iconography.

J. P. Six was the first to suggest a connection between Mausolus and Artemisia and Coan coinage, ${ }^{15}$ and he was followed by George Francis Hill in $1923 .{ }^{16}$ Six and Hill suggested that the Heracles on some of the early Coan tetradrachms was a portrait of the Carian satrap Mausolus disguised as a god (Fig. 3). Likewise, the features of Artemisia could be read into the draped female head on the fourth-century tetradrachm and didrachm issues ${ }^{17}$ (Fig. 4). The main reason for the speculation is a comparison between particular Coan tetradrachms and the so-called Mausolus statue from the Mausoleum, now in the British Museum ${ }^{18}$ (Figs. 5 and 6). Hill observes 'The

15 Weber 1892, 206 (quoting Six on his suggestion that the features of Artemisia could possibly be read into the draped female head on the Coan tetradrachms); Six 1899, 82 (reading the features of Mausolus into the Heracles depiction on the early Coan tetradrachms).

${ }^{16}$ Hill 1923, 208. Hill obviously knew Six's theory of a connection between the female head and Artemisia.

17 A coin type from Lycia is often used to strengthen the argument. The portrait of the dynast Kherei has been read into a depiction of Heracles on coins minted in Telmessos in the first part of the fourth century, see Mørkholm \& Zahle 1976, 85. Konuk (1998, 138) suggests that these Lycian issues 'may have provided an inspiration for the Coan coins' based on the shape of the reverse die (square punch end providing a distinct square incuse and a square border of dots). It is hardly necessary to look for parallels in Lycia for this particular fabric. The mid-fifth century diskoboloi of Cos, significantly earlier in date, are almost identical in fabric to the early tetradrachms with the bearded Heracles and crab introduced in $c .395$. Heracles is firmly rooted in the religious conception of the Coans in the period, and there is no need to look further afield for inspiration.

${ }^{18}$ For illustrations, see Bieber 1955, 71-72; Richter 1965, 161-162. 


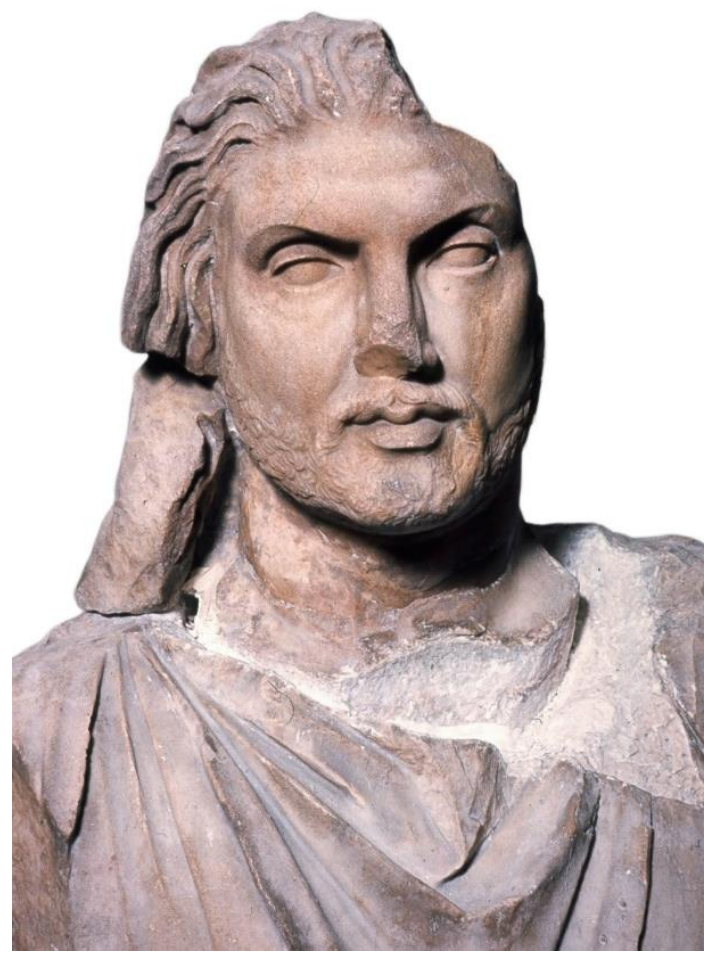

Fig. 5 Head en face of the so-called Mausolus from the Mausoleum in Halicarnassus. Photograph: (c) British Museum, used by permission.

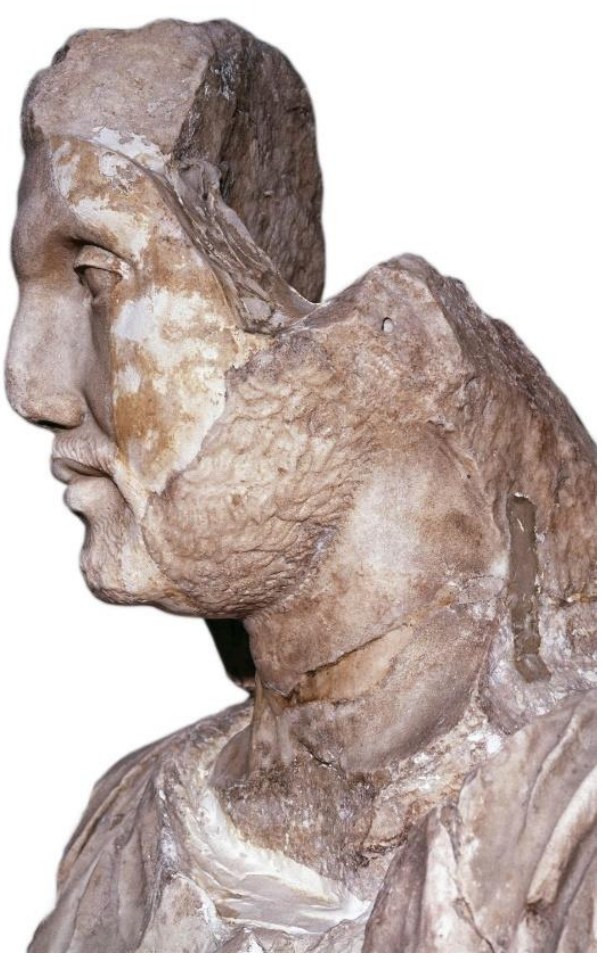

Fig. 6 Left profile of the so-called Mausolus from the Mausoleum in Halicarnassus. Photograph: (C) British Museum, used by permission.

head [on the tetradrachms] is quite different from that which appears on other coins of the period; the silky Oriental moustache, the treatment of the eye, the slight tinge of melancholy, all combine to recall the likeness of the satrap.' He further rightly points out the fact that Mausolus had a strong influence on Cos from 357 until his death in 353 and that his successors kept control of the island well into the 340s. Hill's suggestions were repeated by Susan Sherwin-White: 'Evidence of Mausolus' earlier influence in Cos is provided by Coan coins. [---]. The numismatic material shows that already by the end of the 360s Mausolus' close relationship with the Coans was established. ${ }^{19}$ In adopting Hill's theory without reservation, her further argumentation is based on uncertain evidence. The argument is again repeated by Koray Konuk in his first major study of the Hecatomnid coinage from 1998. ${ }^{20}$ In this study Konuk partly rejects the possibility of interpreting the features of Mausolus into the coin

\footnotetext{
19 Sherwin-White 1978, 70-71.

20 Konuk 1998, 136-143, discusses the attribution of Heracles and Demeter with Mausolus and Artemisia, in addition to the chronological considerations presented in Sherwin-White as a consequence of this interpretation.
} 
depiction of Heracles. ${ }^{21}$ It is necessary here to emphasize that more recently Konuk has abandoned the theory regarding these personal identifications on the coins from Cos based on a revised chronology of Coan coinage. In an article on Hecatomnid coinage and identity from 2013, he writes:

\begin{abstract}
The comparison of course depends on the identity of the statue, which is far from certain. [---]. What is extant is a very small sample of what originally adorned the tomb, and the so-called Maussollos might depict another dignitary. Even if we accept that the statue represents the satrap, there are dies which do not convey the same resemblance as the specimens selected by Six and Hill. 'The 'Hecatmonus hoard' and IGCH 1203 provide evidence that Kos struck a series of tetradrachms with Heracles/crab in the opening decades of the $4^{\text {th }}$ century BC. In other words, the type that Hill and Six illustrated existed before the time of Maussollos. We may therefore be confident that the obverse originally depicted Herakles and was not intended to depict an individual. ${ }^{22}$
\end{abstract}

The identification of the female heads on later fourth-century coin issues follows the same pattern. Already in 1892 Weber (partly quoting Six) discusses the attribution to Artemisia, although he also expressed his reservations: 'and further, the ideal beauty of the head seems to me to belong rather to a deity than to the portrait of a human being' ${ }^{23}$ Svoronos observed some of the stylistic divergencies of the female heads, and he suggested, for stylistic reasons, an interpretation of the motif as the Egyptian Berenice $I .{ }^{24}$ Hill solves this problem by separating the female head coins into two separate types; one identified as Artemisia and the other with 'a stiff and curiously Egyptian look' as Berenice ${ }^{25}$ (Fig. 7). At an early stage, in his study of 1998, Konuk follows Six, Hill, Weber and Svoronos in identifying the draped female head with Artemisia, presenting several arguments, the most significant being that Demeter, especially draped, is rarely seen on Carian coinage of the period, in addition to the peculiarity of placing two gods on either side of a coin. In his early study, Konuk concludes that: 'the appearance of a draped woman c. 350, of a type attested in Hecatomnid sculptural iconography, cannot be just a mere coincidence, [this makes] a strong case for regarding it as a depiction [--] of either Artemisia or Ada I. All in all, it would not be surprising if the city decided to honour a Carian female dynast on its coinage' ${ }^{26}$

${ }^{21}$ Konuk 1998, 137: '- the type that Hill and Six illustrated existed before the time of Maussollos'. He goes on to discuss the possibility that the Heracles depiction might have evolved at a later stage into a personification of Mausolus.

${ }^{22}$ Konuk 2013, 109 and n. 56 with reference to Ingvaldsen 2002.

23 Weber 1892, 206.

${ }^{24}$ Svoronos 1904-1908, 41-43 (or column 81-86 as given in Greek numerals in the work). The absence of convincing arguments in Svoronos' attribution is commented on in Ashton 1986, 13 note 31 , where convincing objections to his stylistic analysis are presented.

${ }^{25}$ Hill 1923, 208-209.

${ }^{26}$ Konuk 1998, 140. 


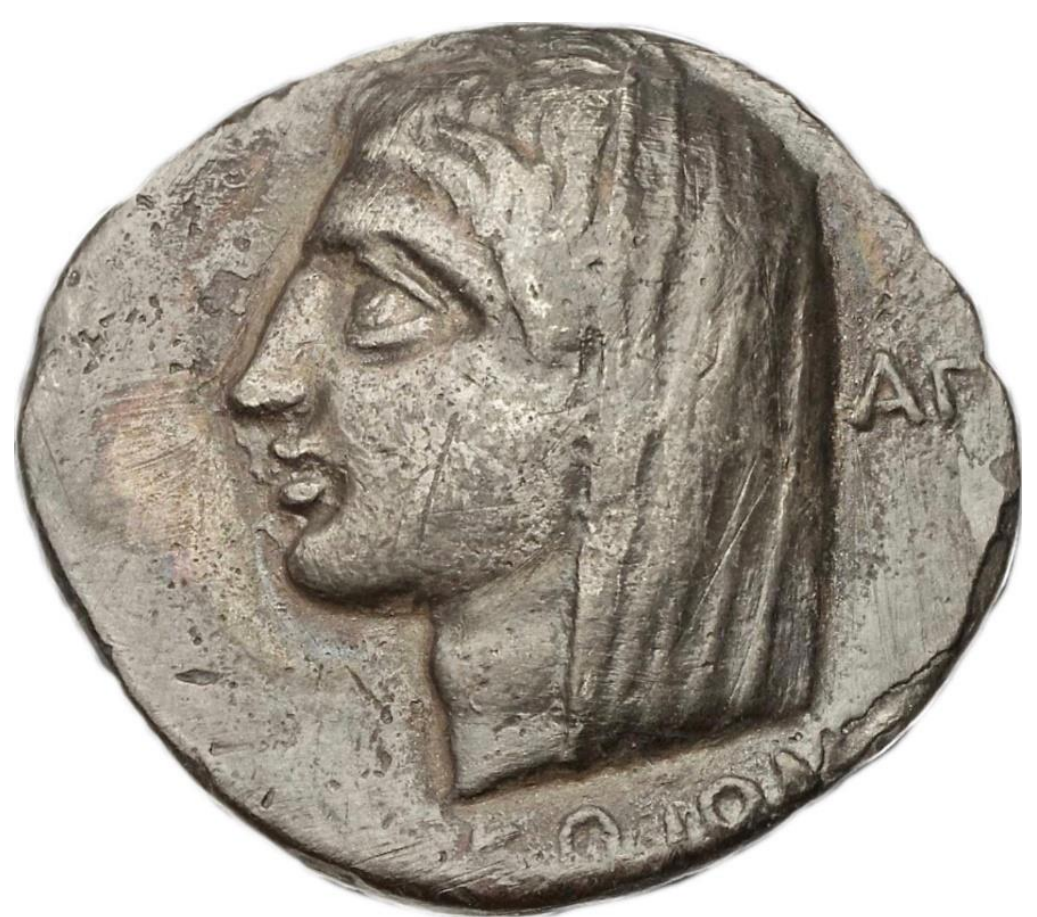

Fig. 7 Coan didrachm with female head, c. 340 BCE. Photograph: (C) Classical Numismatic Group LLC.

Again, this theory of attribution is not evidence-based. If Mausolus is not part of the sculpture group, neither is Artemisia. And any likeness between the female head and coin renderings is purely speculative since the facial features of the sculpture are damaged and unidentifiable based on facial similarities (Figs. 8 and 9). The suggestion that Berenice was also depicted is purely fictional (see arguments below). ${ }^{27}$ The identification of Mausolus, Artemisia or Berenice on Coan coinage has no root in evidence since it depends solely on the likeness between the so-called Mausolus statue (there is no evidence either that it was Mausolus or that it was not, see below) from Halicarnassus and a limited number of coins from the presumably earliest tetradrachm series of Cos. Based on this we must conclude that the misinterpretation of 'portraits'

\footnotetext{
${ }^{27}$ This attempt at identification clearly demonstrates the strong appeal it has had among scholars to try to link historical figures to sculptures. Another example from Halicarnassus is the upheaval that followed the discovery of the 'Carian Princess' in Bodrum in 1989, which attracted a lot of attention through an exhibition from 1993. The remains of a female discovered in a richly equipped sarcophagus were exhibited. The attempt to reconstruct her appearance based on forensic facial reconstruction caused a heated debate, which was later described as "The sometimes frenetic and occasionally hilarious activity that became a feature of the reconstruction of the Carian Princess' Prague \& Neave 2010, 109.
} 


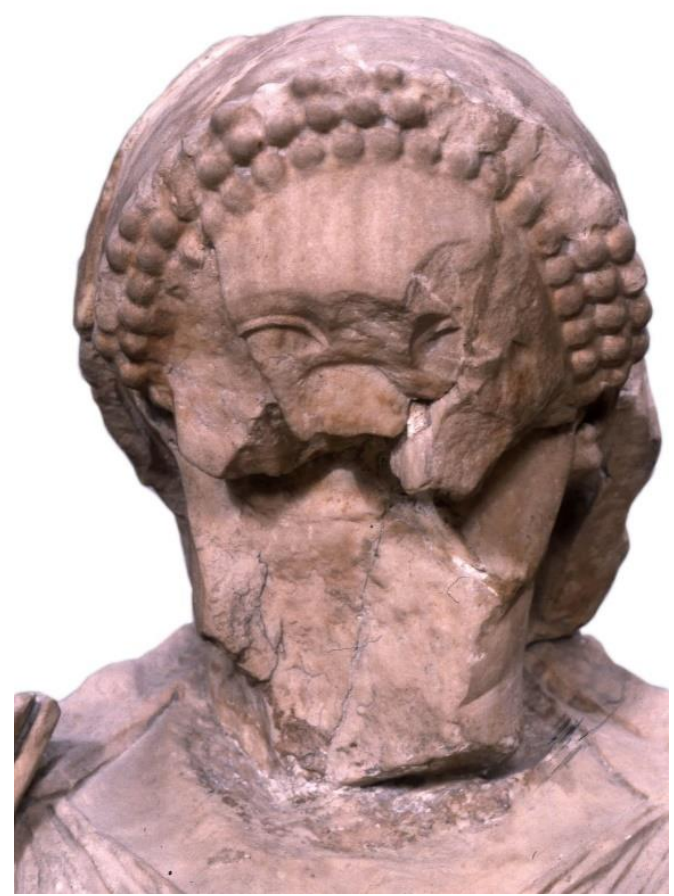

Fig. 8 Head en face of 'Artemisia' from the Mausoleum in Halicarnassus. Photograph:

(C) British Museum, used by permission.

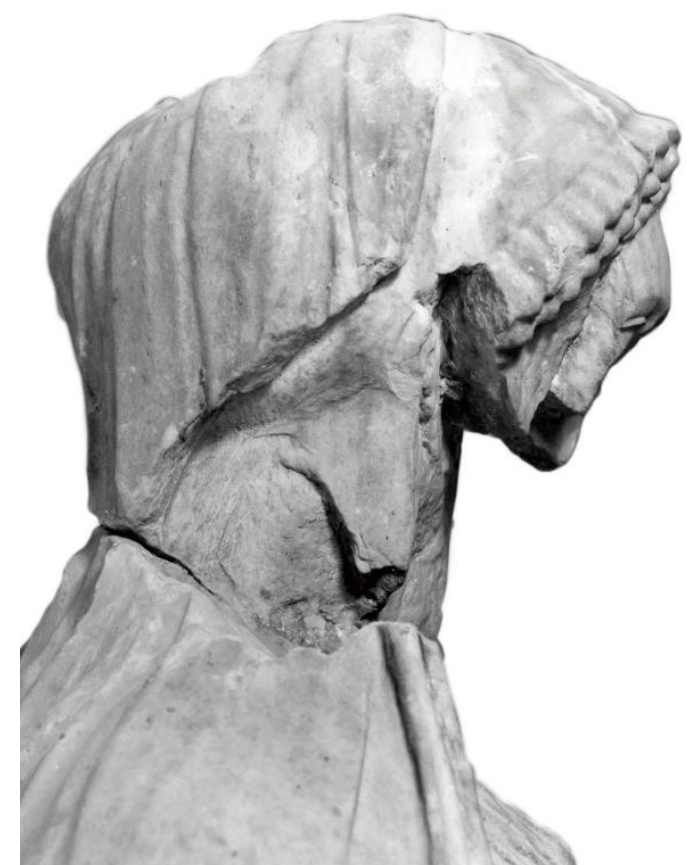

Fig. 9 Profile head of 'Artemisia' from the

(C) British Museum, used by permission.

has led to uncertain hypotheses and wrong conclusions about important historical events in fourth-century Caria being repeated over and over again. ${ }^{28}$

\section{Re-examining the sources}

Numerous arguments speak against these attempts to identify individuals in depictions of deities on $\operatorname{coins}^{29}$, but two are decisive. Firstly, the statue from Halicarnassus cannot be securely identified with Mausolus. Since the satrap's physical appearance is unknown from other sources the identification of him on Coan coins is impossible to

28 The presumed identification of Mausolus and Artemisia on Coan coinage has also entered the international art market, where it is in danger of becoming a self-confirming 'truth' by being repeated over and over again. See e.g. https://www.asiaminorcoins.com/gallery/displayimage. php? album=216\&pid=2513\#top_display_media.

${ }_{29}$ For example, that the use of portraits on coins in this way is an unknown practice at such an early stage; that the visible signs of Mausolean control on Chios and Rhodes are manifested on the coinage with obvious elements such as the adoption of Halicarnassean coin types on Chios and a satrapal head as additional symbol on Rhodes - in contrast to a vague and hidden sign as a disguised Mausolus portrait; that only a few dies in the Coan issues in question have 'oriental' features which would have made it practically impossible to separate them from the coins with 'only' Heracles as the motif. See Demosthenes 15.5.25 for Hecatomnid influence and the establishment of an oligarchy on Rhodes and Chius. 
confirm. The sensational discovery in 2010 of what appears to be Hecatomus' grave monument in Milas (ancient Mylasa) may provide new evidence on the physical appearance of Mausolus. However, it is not possible to include this in the discussion here as we still lack a detailed scientific publication of the findings. ${ }^{30}$ Secondly, the Coan coinage in question with Heracles-head was introduced long before the reign of Mausolus and continued until long after his death. Furthermore, the veiled female head coins were minted long after Artemisia's death in 350, and the two stylisticallydifferent types of female heads were minted almost simultaneously. ${ }^{31}$

Regarding the first point, the suggestion that the well-known statue from the Mausoleum represents Mausolus has been rejected and restored on several occasions. Because of this, the sculpture is most often called the 'so-called Mausolus', or is described in similar terms that reserve themselves against a secure identification of the king. ${ }^{32}$ The main publications on the Mausoleum clearly reveal the uncertainties surrounding the reconstruction and attribution of the sculptures in the round. ${ }^{33}$ The body of research on the Mausoleum is too extensive to go into in any detail. The most important point for further discussion is that no consensus has been reached on the identification and attribution of the round sculptures. Here, I essentially follow the conclusion reached by Geoffrey B. Waywell, who first published the sculptures from the Mausoleum, now in British Museum, and the former director of the Danish

\footnotetext{
${ }^{30}$ Illegal excavations in Uzunyuva in 2010 uncovered what appears to be the monument and sarcophagus of Hecatomnus. The sarcophagus has carved reliefs on all four sides with a funerary banquet scene as the main motif. The composition is conventional, but each figure is produced with sufficient individual physiognomic features to be called individual representations and not mere idealizations of a dynastic family. We still face the same problem here as in the personal representations in the mausoleum in Halicarnassus in that we do not know who the various figures represent. Attempts to identify the individual members of the dynasty, possibly with the exception of Hecatomnus himself and his wife Aba, therefore remain speculative. There are also paintings depicting the king and queen with servants or relatives on the narrow walls of the tomb, but again it is impossible to identify individual representation of members of the Royal family. The sarcophagus and murals have not yet been published in enough detail for us to make a thorough comparison with the sculptures from Halicarnassus. Interesting research is underway which, among other things, is based on photogrammetric models for comparison between the personal representations in Halicarnassus and the new findings from Milas. See Isik 2019 for the wall paintings; Rumscheid 2010 for the motifs on the sarcophagus; and Verdiani et al. 2017 for a preliminary comparison between the monument in Milas and the Mausoleum in Halicarnassus.

${ }^{31}$ It even reappears on bronze coins in the second half of the third century.

${ }^{32}$ Hellström 1993, 72: 'Identification with Mausolus has been questioned since its discovery in the mid-19th century'. See e.g. 'Mausolus (?)' in Boardman 1973 (1981), 137; The British Museum, Internet catalogue, Museum no. 1857,1220.232: 'The so-called 'Maussollos'. Available from URL: https://www.britishmuseum.org/collection/object/G_1857-1220-232 [Visited 17 November 2020].

${ }^{33}$ Jeppesen 2002, 62-68; Waywell 1978, 25, sculpture nos. 26-27.
} 
excavations at Halicarnassus, Kristian Jeppesen, in their main publications of the round sculptures and the reconstruction of the Mausoleum. ${ }^{34}$

In short, Jeppesen raises three objections against identifying the statues in question as being the two sculptures in the chariot crowning the Mausoleum, i.e. supposedly Mausolus and Artemisia: 1) they do not correspond in scale to the horses of, allegedly, the same group; 2) in the chariot the sculptures would have been visible from all angles, but the two in question both show a cursory treatment of their backs more in line with the treatment of most of the standing figures of the Mausoleum intended to be standing against a wall; 3) the stance of the two statues does not correspond convincingly with a position in a chariot. The female figure has her arms raised 'in a gesture of adoration and subordination', and this attitude does not correspond to the placement of her next to her co-ruler and equal in a chariot. Jeppesen has previously supported this author's view that there are no indications that connect the so-called Mausolus with the Heracles on Coan tetradrachms. ${ }^{35}$ This is based first and foremost on the studies put forward by Jeppesen and Waywell, but also on the inability of other scholars to reach other convincing conclusions, and it is now generally accepted that the statues are not of Mausolus and his wife Artemisia, but rather of succeeding rulers.

Secondly, a review of the Coan coin material in no way supports the argument for identifying Hecatomnid rulers in the disguise of Heracles or/and Demeter. The evidence for this is found in two different fields of examination: the chronology of the coin issues in question and the style of the die-cutters.

The chronology of the coins issues is of course decisive for the argument for identifying Mausolus and/or Demeter on the coinage. Two major coin hoards have contributed significantly to our understanding of the chronology of the silver issues in question. The first is the so-called Hecatomnus-hoard, discovered in 1977 near Söke in Western Turkey. After many years of investigations, 342 coins have been identified from this large hoard, which was smuggled out of Turkey and sold to collectors worldwide. In short, the hoard proves beyond doubt that the earliest Coan coin issues with Heracles and the crab preceded not only the Coan synoecism in 366 but also Mausolus' reign by several decades. ${ }^{36}$ The next hoard is the so-called Pixodarus-hoard, discovered near Bodrum (ancient Halicarnassus) in 1978. The 2600 coins were again smuggled out of Turkey and sold on the market. But, a major part of it has now been reconstructed. This hoard is important since the many Coan coins made it possible to establish the sequence and chronology of the second and largest silver issues with the bearded Heracles/crab, and bearded Heracles/veiled female head. The first was

34 The Danish excavations at Halicarnassus have been published in seven volumes from 1981 to 2004 (The Maussolleion at Halikarnassos. Reports of the Danish Archaeological Expedition to Bodrum). Jenkins 2010 gives a useful survey of the three main suggestions of reconstruction, i.e. Waywell 1978, Jeppesen 1998 and 2002, and Hoepfner 1996 and 2013. See also Cook 2005 for the relief sculptures, and Jenkins 2006 for a more recent publication of the sculptures in the British Museum.

35 Pers. Comm. (letter of 15 July 2000).

${ }^{36}$ CH IX, no. 387; Stefanaki 2012, Series IV (dated 400-380). 
minted c. 370-345 and the latter c. 345-340. ${ }^{37}$ The conclusion is that the Heracles-issues were introduced long before the reign of Mausolus and continued until long after his death. Furthermore, those with the veiled female head were minted long after Artemisia's death in 350. The design even reappears on bronze coins in the second half of the third century. ${ }^{38}$

To rule out the possibility of identifying any portrait likeness in the Heracles and/or veiled female heads, the full corpus of Coan coinage must be taken into consideration. Of the coinage in question, a total of 40 dies with bearded Heracles and 43 dies with a veiled female head have been identified. ${ }^{39}$ With some imagination, we can actually see some superfluous likeness between the so-called Mausolus sculpture and some of the Heracles heads on the coinage. ${ }^{40}$ They share common features such as a small and deeply set eye with a heavy upper eyelid, small and full lips, protruding bone structure in the lower forehead and a full beard. But we can also find differences, like the cropped beard and long flowing hair — a Hecatomnid trademark — on the so-called Mausolus, features that are absent from the coin images. These stylistic similarities are observed only on a few individual dies in the latter part of the major issue of tetradrachms with the crab on the reverse from shortly before 345 . In a closer examination, it becomes apparent that there is a significant variety in the Heracles depiction within the same coin issue. ${ }^{41}$ The first four obverse dies (on the coins of Xanthippos, Philiskos and Lykon) are almost identical, and are probably the product of the same die-cutter (Fig. 10, nos. 189-197). The same person also produced the later dies on the coins of Dion. ${ }^{42}$ Furthermore, the resemblance is striking among the obverse dies of Amphitimos, Phylotimos and Praxianax ${ }^{43}$ (Fig. 11, nos. 221-223). But we can also find great variation in style, e.g. in the remaining dies of Dion (Fig. 11, nos. 210-216), and a particular style without parallel in other issues on the dies Ingvaldsen O5 and O6: the head itself is small, with large eye and nose, the lion's scalp forms a straight line from Heracles' ear to the forehead, and small locks of hair run like a border of dots along this line (Fig. 10, no. 202). A more standardized Heraclesrendering is established in the last part of the issue, with a slightly smaller lion's scalp with a straighter line at the back of the head, and more stylized and claw-shaped locks of the lion's mane. ${ }^{44}$ The latest dies of this issue are very similar in style, many of them clearly the product of the same die-cutter (Fig. 12). These are also the coins that are commonly compared to the so-called Mausolus head. Thus, any likeness to an

\footnotetext{
${ }^{37}$ CH IX, no. 421; Stefanaki 2012, Series V (dated 370/60-345) and Series VI (dated 345-340). 38 Ingvaldsen 2002, Issue XVII (dated 250-200).

39 Ingvaldsen (Roland) 2002.

${ }^{40}$ For example, Stefanaki 2012, 451 (obverse dies on plates) as compared to the profile head in Hill 1923, pl. 10, and Fig. 6 above, and Fig. 12.

41 Stefanaki 2012, Series V; Ingvaldsen (Roland) 2002, Issue VI.

${ }^{42}$ Ingvaldsen O8, O10.

43 Ingvaldsen O11, O12.

44 Ingvaldsen O12-O20.
} 


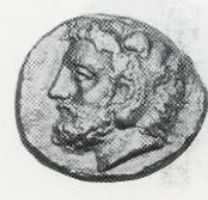

175
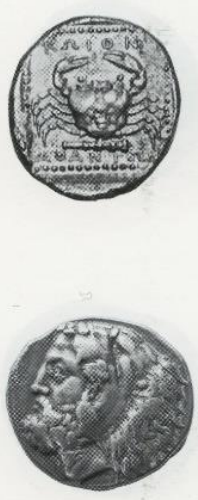

190
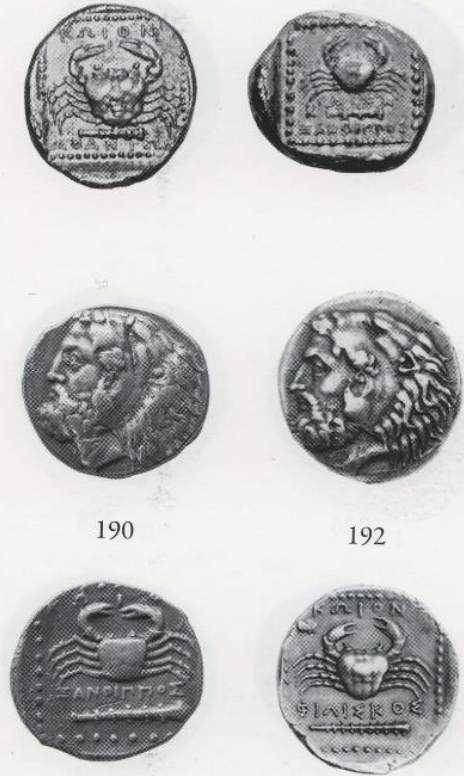

192

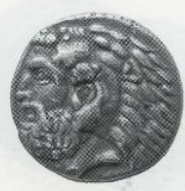

197
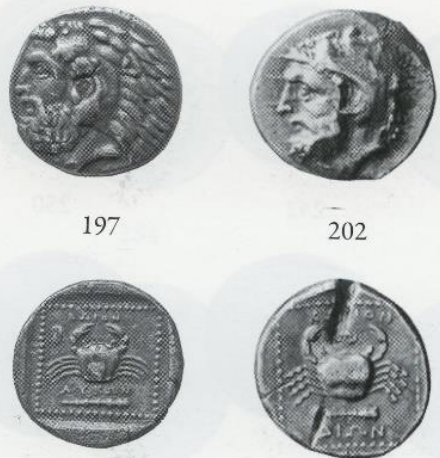

202
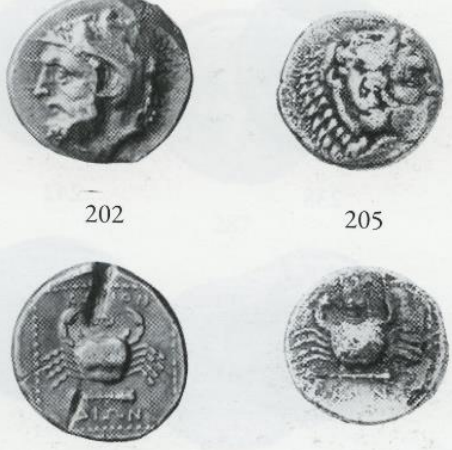

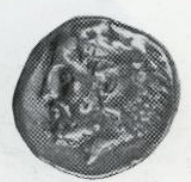

207

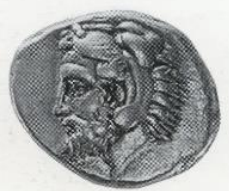

189
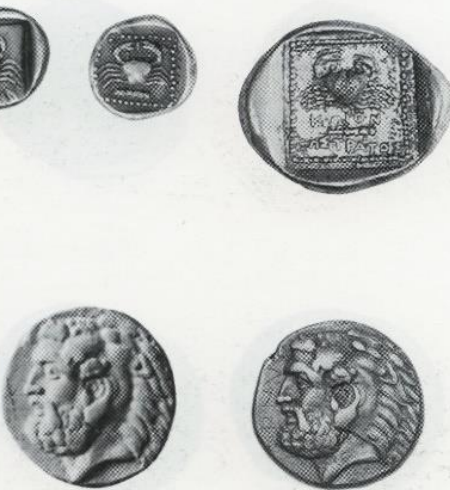

194

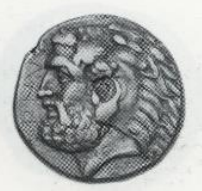

195
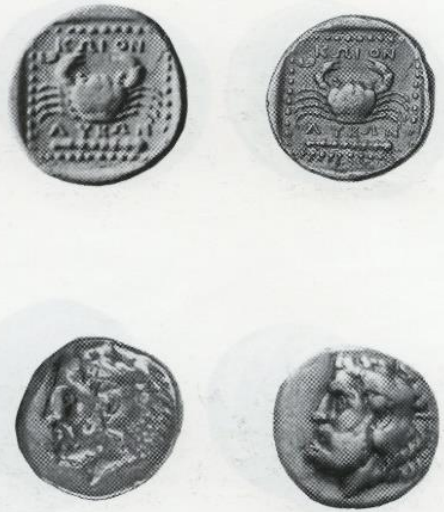

208
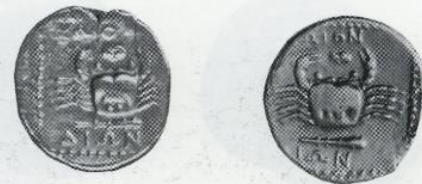

Fig. 10 Coan tetradrachms. Heracles/crab-type issued before the reign of Mausolus. Photograph from: (C) Stefanaki 2012, plate 449. 


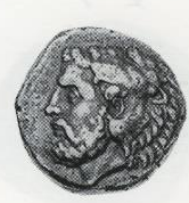

210
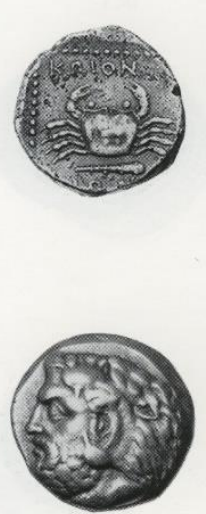

221
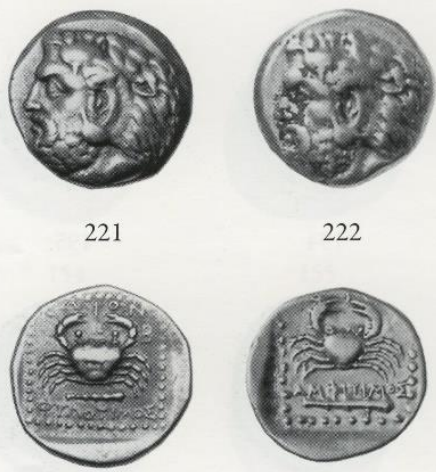

222
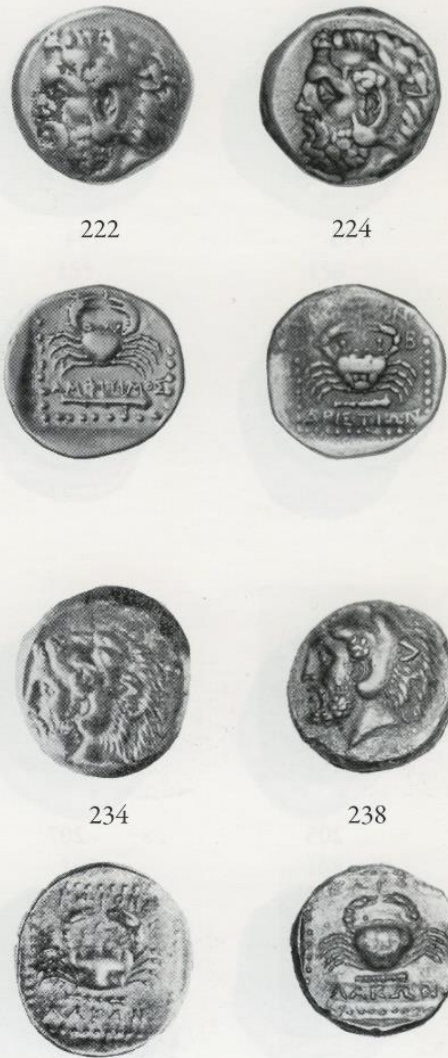

224

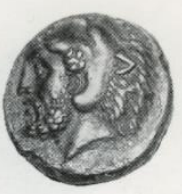

238
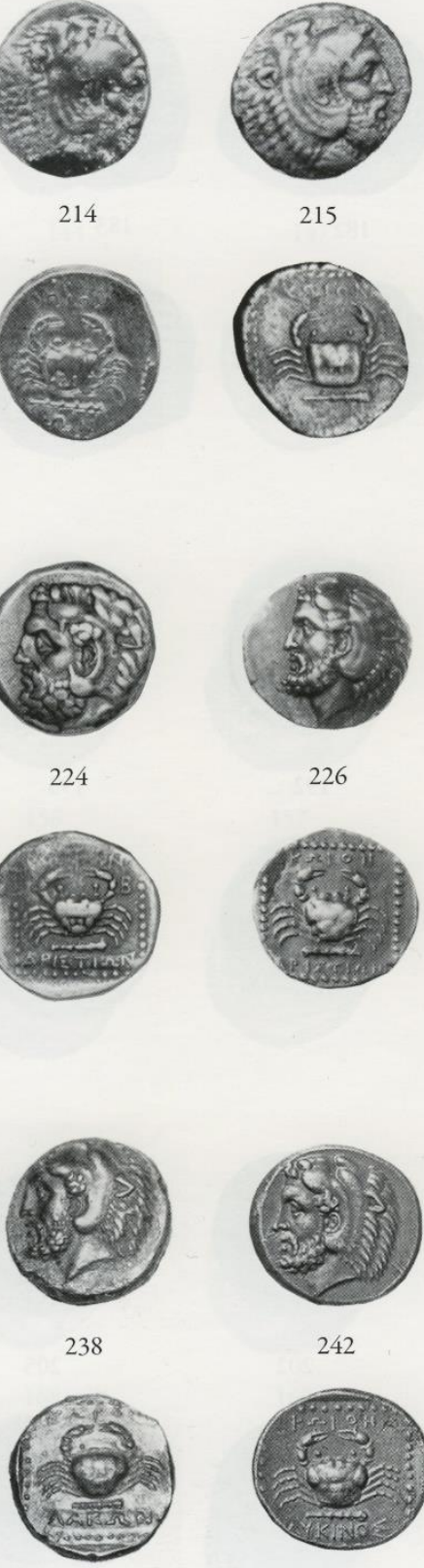

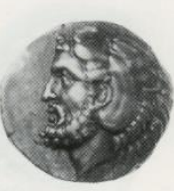

215

226
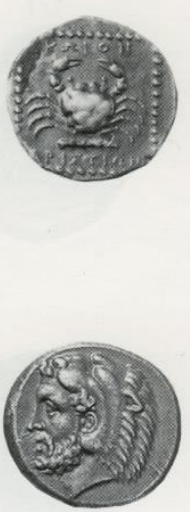

242

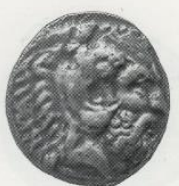

216
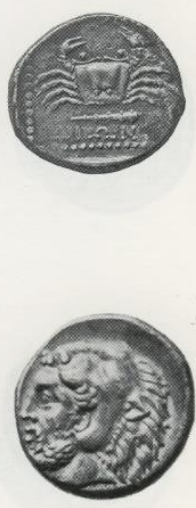

228
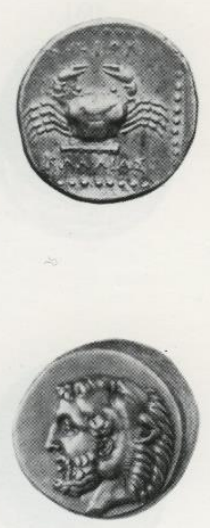

250
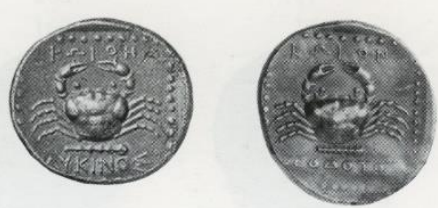

Fig. 11 Coan tetradrachms, variety of styles of the Heracles head. Photograph from: @ Stefanaki 2012, plate 450. 


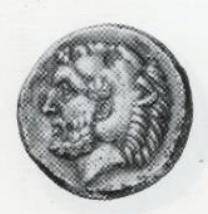

252
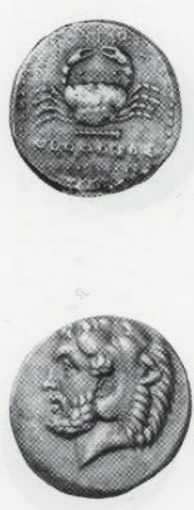

270

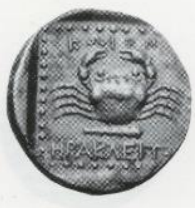

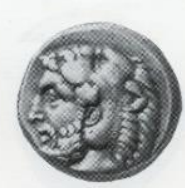

255
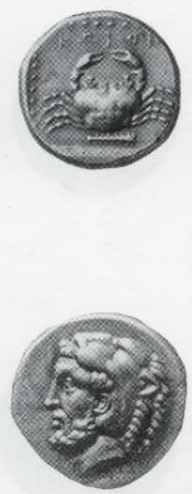

271

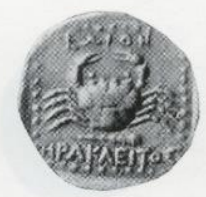

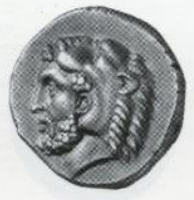

260
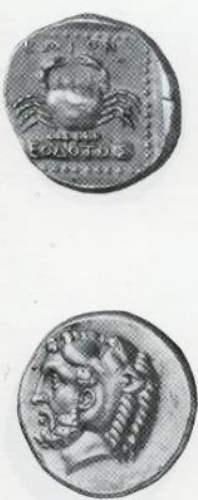

273

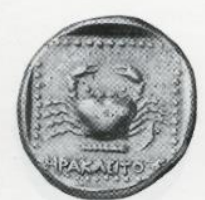

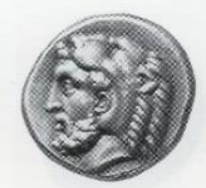

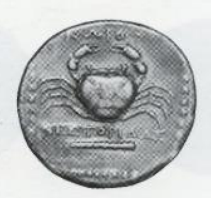

261
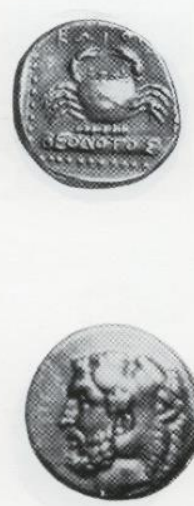

275
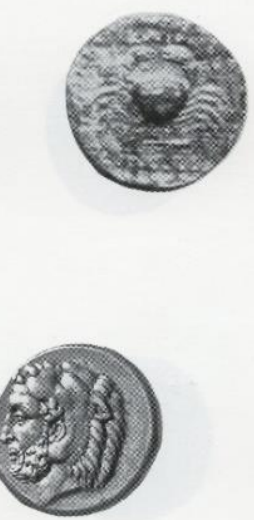

289

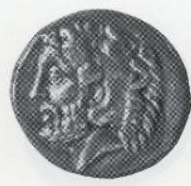

269
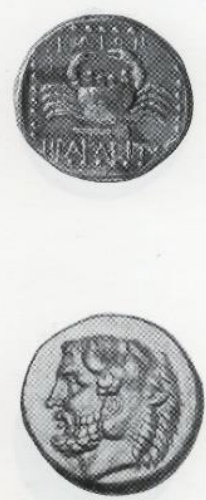

280
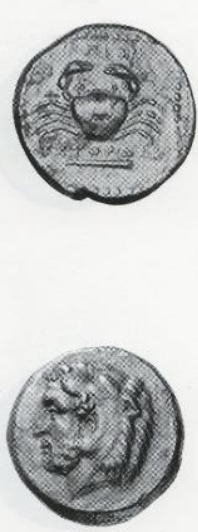

290
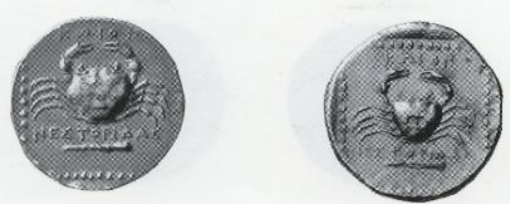

Fig. 12 Coan tetradrachms, later dies typically used in comparison with the so-called Mausolus from the Mausoleum in Halicarnassus. Photograph from: (C) Stefanaki 2012, plate 451. 


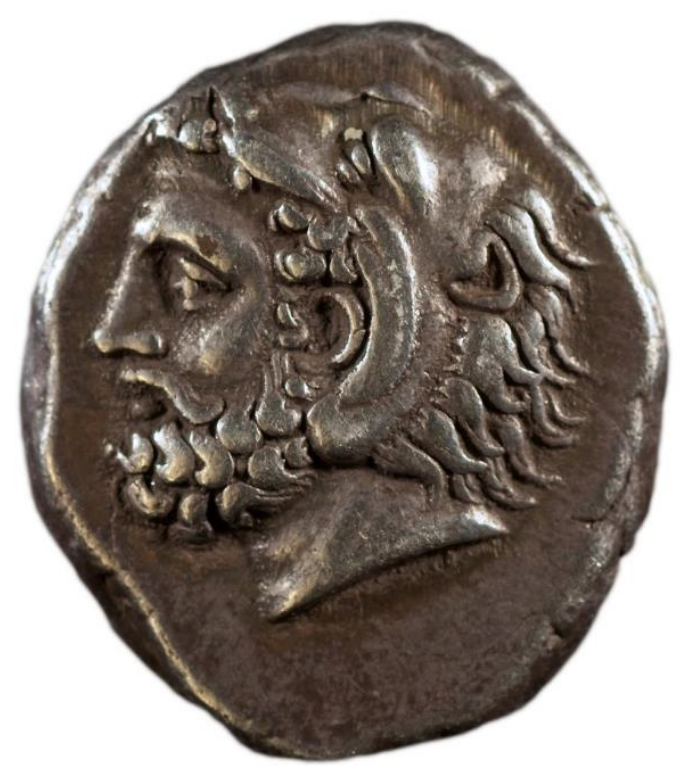

Fig. 13 Coan tetradrachm with Heracles head, c. 380

BCE. Photograph: (C) H. Roland, Museum of

Cultural History, University of Oslo.

individual or to the sculpture in question is simply reduced to the individual style of a single die-cutter (Fig. 13). ${ }^{45}$

As mentioned above, the veiled female head falls into two significantly different stylistic groups. However, the coin chronology demonstrates that the difference is, again, due to different styles of execution by different die engravers. ${ }^{46}$ Both stylistic groups are represented in coin issues minted within a five-year period. We have no reason to believe that two different women were portrayed during this short time. ${ }^{47}$ If the Hecatomnid sister-wives were in fact represented on Coan fourth-century coinage this would represent an unprecedented use of the features of a co-ruler disguised as a goddess in a city-state coinage of the Classical period. The representations of the sister-wives of the Hecatomnid rulers were often draped in a manner close to the head on the Coan coinage, but this iconography is by no means exclusive to the Hecatomnids. ${ }^{48}$ An unidentified marble statue of a draped woman found in the Odeion on Cos displays a certain likeness to the head-on type 1 of the Ingvaldsen issue III and IV coins, in its sharp profile, smooth and thin drapery and small, rounded curls of the hair. Kabus-Preisshofen suggests a date for the statue in the late fourth

45 See also Stefanaki 2012, 448-452, nos. 154-313.

46 Stefanaki 2012, Series VI; Ingvaldsen (Roland) 2002, Issue III-V.

47 Ingvaldsen (Roland) 2002, 65-70; Ingvaldsen (Roland) 2002a, 116; CH IX, 240.

48 Prag \& Neave 1994, 102-103; also, the 'Artemisia' sculpture from the Mausoleum is damaged beyond recognition, and thus any meaningful comparison to the Coan coin issues is ruled out (see above, and Figs. 8 and 9). 
century. ${ }^{49}$ Even more interesting is another Coan draped female head found on the acropolis of Rhodes, identified as Demeter by Kabus-Preisshofen, partly due to a comparison with the Cnidian Demeter, and dated to c. $300 .{ }^{50}$ The thin drapery, wavy, short curls of the hair, deeply set eye with strongly marked eyebrows and protruding forehead all recall stylistic similarity to a few dies of the Coan coin issue Ingvaldsen III. ${ }^{51}$

If we consider all the recorded dies of the draped female head-issues we will notice a wide variation in style and facial features, and it becomes clear that there is no established 'portrait-type' at all. Furthermore, the 'stiff, and curiously Egyptian' coins are without doubt contemporary to the more vivid depictions associated with Artemisia. The issue was limited and minted over a short time, probably only a fiveyear period (see below). There is no reason to believe that two separate individuals were represented on the coinage during such a short period.

Two die-cutters have produced the reverse dies of Ingvaldsen issue III, type 1. The dies Ingvaldsen R1 and R2 are clearly the product of one and the same hand, characterized by a small eye, narrow and sharp folds in the drapery and the small, horizontal hair locks above the ear (Fig. 14, nos. 464, 466). Ingvaldsen R3, with a large, staring eye with clearly marked pupil, sharp, straight profile and stylized and flat folds in the drapery, is made by a different person (Fig. 14, no. 471). The identification of die-cutters is more difficult in Ingvaldsen issue III, type 2. The 12 reverse dies in type 2 show great variations in style. Ingvaldsen R4 (of Athamas) and R8 (of Philodamas) are probably by the same hand (Fig. 14, nos. 474, 493), as are Ingvaldsen R6 and R10 (Athamas and Philodamas) (Fig. 14, 485; Fig. 14, 509). Ingvaldsen R11, R12 and R15 (all of Biton) show strong similarities (Fig. 15, nos. 525, 535), as do Ingvaldsen R13 and R14 (both of Biton). Thus, it seems that approximately nine different die-cutters have produced the 15 reverse dies of Ingvaldsen issue III. What separates the type 1 and type 2 stylistically can best be illustrated by a comparison between Ingvaldsen R1 (type 1) and Ingvaldsen R8 (type 2). The stiff and stylized facial features combined with the flat and lifeless drapery of Ingvaldsen R1 is curiously different from the naturalistic rendering of Ingvaldsen R8 (Fig. 14, 461 vs. 493). The delicately shaped face with beautifully executed eye and mouth, in combination with the drapery falling naturally down in realistic folds from the crown of head, stands out in stark contrast to Ingvaldsen R1 and the other two reverse dies of type $1 .{ }^{52}$

The conclusion based on a comparison of the Mausoleum sculptures, related Coan sculptures and the individual dies of the relevant coin issues must be that the

${ }^{49}$ Cos Museum, 13 (Rhodes inventory 13579). Kabus-Preisshofen 1989, n. 51.

${ }^{50}$ Rhodes, mag. n. 1985: G 92. According to Kabus-Preisshofen the Demeter head was found together with a Heracles head, see Kabus-Preisshofen 1989, 304, and catalogue n. 98.

${ }^{5}$ Ingvaldsen (Roland) 2002, Issue III, die R4; cf. also Stefanaki 2012, 456, n. 476.

52 See also Stefanaki 2012, 456, n. 461 (Ingvaldsen die R1) and no. 493 (Ingvaldsen die R8). A similar pattern is seen also in the related Ingvaldsen Issue IV of didrachms. Apparently, no new die-cutters were employed for this issue. See Ingvaldsen (Roland) 2002, Issue IV, type 1 and 2; see also Stefanaki 2012, Series VI. 


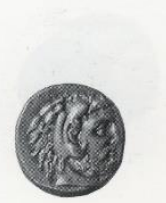

455

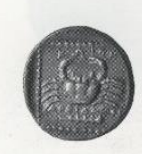

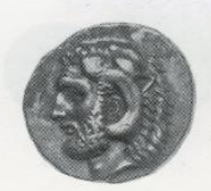

461
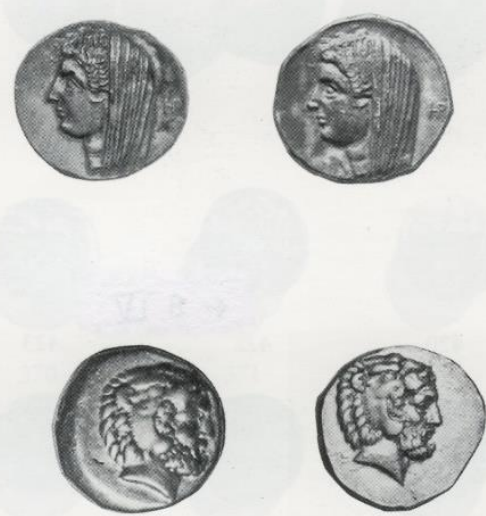

474
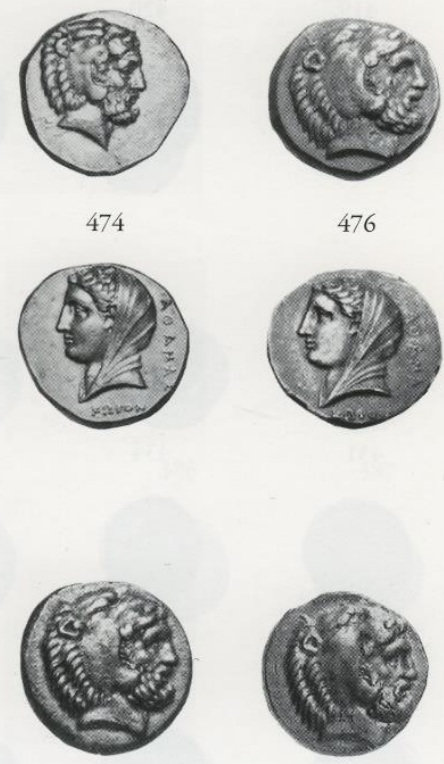

476

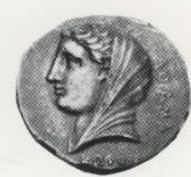

496

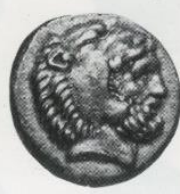

493

491
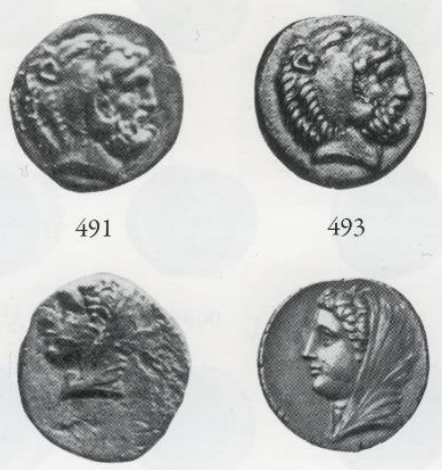

464
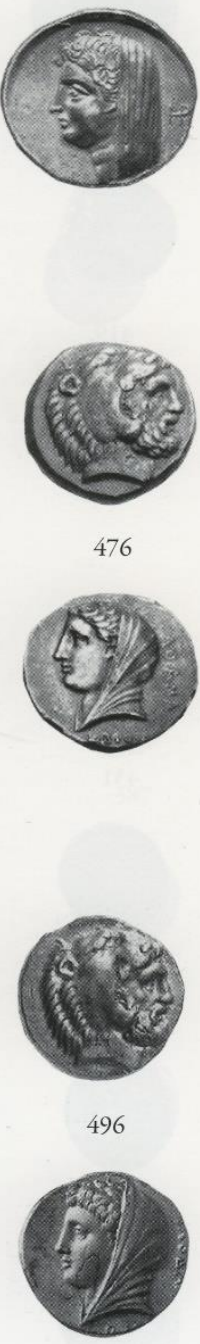

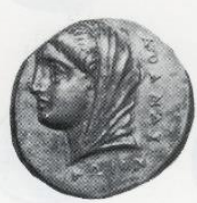

Fig. 14 Coan tetradrachms with Heracles and Demeter, variety of types and dies. Photograph from: (C) Stefanaki 2012, plate 456. 


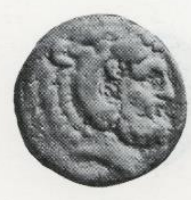

506
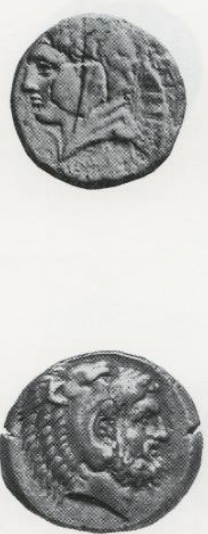

526
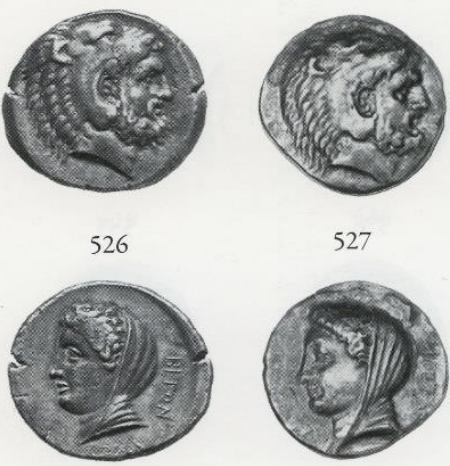

527
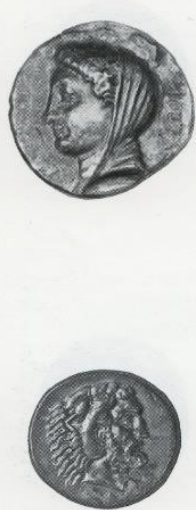

53
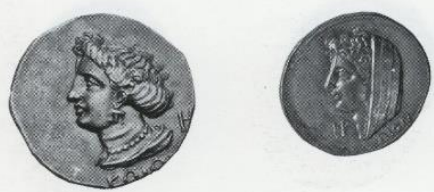

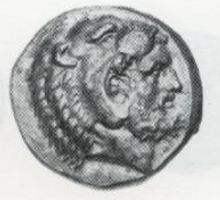

510
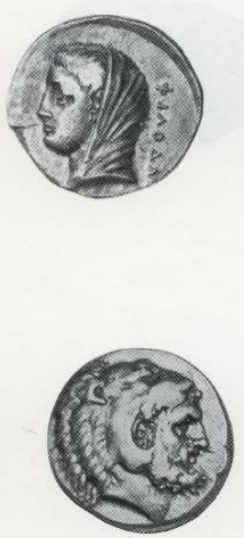

528
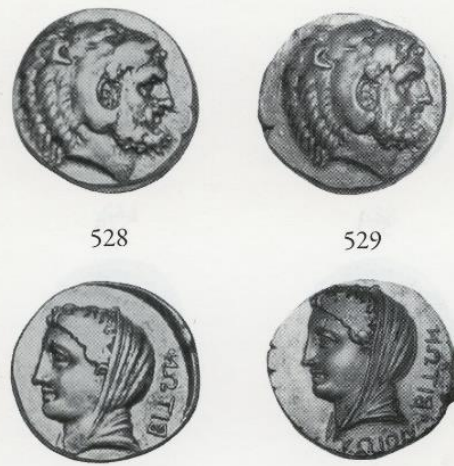

529
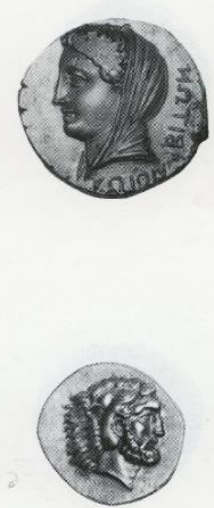

539
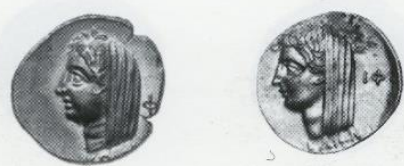

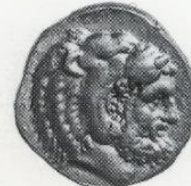

525
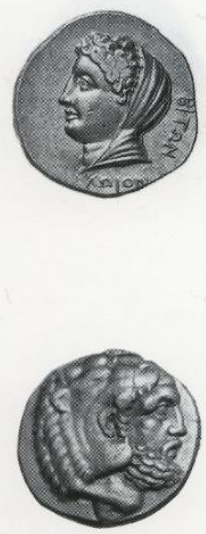

535
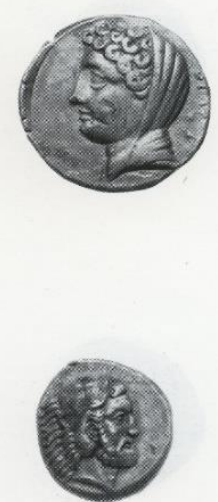

540

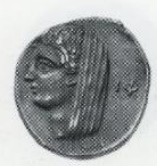

Fig. 15 Coan tetradrachms and didrachms with Heracles and Demeter, variety of types and dies. Photograph from: C) Stefanaki 2012, plate 457. 
coin images of Heracles and Demeter can in no way be considered as hidden 'portraits' of Carian rulers and/or Egyptian queens. The theory of portraits of Hecatomnid rulers on Coan coinage in the fourth century must be firmly rejected.

\section{Discussion}

Despite the lack of evidence, reputable scholars have until recently based historical narratives on the assumption that portraits of Carian dynasts appear on Coan coinage. The following discussion is devoted to the key question of why this narrative gained such strong support despite being contrary to the existing empirical sources. The discussion will aim to identify biased conceptions of style (e.g. 'orientalizing') and the tendency to over-emphasize coins as political symbols (of oligarchs or autonomous poleis) in previous research, and discuss how this might have influenced the interpretation of portraits in Caria and coin motifs on Cos.

As we have seen above, the connection between Coan coin motifs and Carian rulers has its offspring in the argument used by Hill in 1923 when he identified Mausolus on the Coan coin issues: he, followed by others, described the stylistic development in Coan fourth-century coinage with the Heracles motif as 'Orientalizing', with a 'silky, Oriental moustache, the treatment of the eye, the slight tinge of melancholy' that supposedly recalled the likeness of the satrap. Furthermore, the style of some of the female heads is described as 'stiff, and curiously Egyptian', as another sign of an opposition between the Greek and the Oriental, the typical and unusual. As we have seen above the individual style of die-cutters attested by the corpus of Coan coinage did not match the scholarly expectations of a proper 'Greek' style and was probably interpreted based on modern concepts of what is 'Greek' (i.e. Western) and what is 'Oriental'. ${ }^{33}$ When unexpected stylistic expressions were observed in the material culture of a democratic Greek city-state, explanations were perhaps sought based on the scholar's perception of what was expected of a Greek versus a Persian/oligarchic culture, rather than the objects and empirical evidence itself. The identification of individual, veristic features on the coinage was based partly on stylistic elements associated with the 'Oriental' and with Egypt, and partly on a biased concept of a Carian oligarch who was assigned expansionist ambitions to establish a Carian Kingdom, a combination and narrative that may have proved to be irresistible to twentieth-century European scholars. It was considered unlikely that a democratic Greek polis could produce objects reminiscent of 'Oriental' despotism or Egyptian 'stiffness'.

The underlying assumption among some historians could be that as subject to a Royal power, and without the participating institutions usually associated with the Greek polis, Mausolus was unable to reach for the Greek ideal he supposedly had. The invitation of famous philosophers, artists and architects to the royal court, and placing the king's portrait in godlike disguise on the coinage of a nearby Greek polis,

${ }^{53}$ See e.g. Venturi 1963; Vidal-Naquet 1964 and Hall 1989 for the long-lasting scholarly tradition emphasizing the dichotomy between Western freedom and Oriental despotism. 
could be interpreted as an attempt to inject some 'Greekness' into his person and to satrapal rule. Such reasoning could partly explain the twentieth-century scholarly attempts to prove that Mausolus, and possibly his succeeding rulers, placed their portraits on the Coan coinage. The question addressed below is whether one can go further and link this theory to a concept as charged as 'Eurocentrism' and an unspoken premise that Oriental despots first and foremost held the Greek polis and 'Greekness' as the highest ideal.

This reasoning can be passed on to the more fundamental and possibly unconscious concepts of the 'East' and the 'West' that earlier research was sometimes unaware of. ${ }^{54}$ Today, to a certain degree, discussions on contemporary as well as historical matters still revolve around the great divide between considering Greece as the source of everything purely 'European', or as a historical construction based on a fragmentary geographical area formed by cultural assimilation, a divide that has strongly influenced scholarly research and interpretative theories and models in the eighteenth- to twentieth centuries. ${ }^{55}$ However, criticism towards Eurocentrism in history research is today increasingly embedded in the field of archaeology and history. ${ }^{56}$ Much of the 'Eurocentric' research within archaeology and history evolved around the concept of the Greek polis, and served to differentiate the Greeks, and thus more or less consciously liberty and democracy, from Oriental monarchies and despotisms. As Kostas Vlassopoulos sums up: 'The polis has functioned as a boundary mark to separate the history of the Greek communities from those of the Near East. This was accomplished by the construction of a contrast between the Greek polis as a community of citizens and Oriental despotism.' He continues, 'The orthodox view that formed the juxtaposition between the world of the Greek polis and the redistributive bureaucratic monarchies of the Orient is grossly misleading.' ${ }^{57}$ It is worth noting that examples of the opposite also have relevance for the subject of this article. $^{58}$

54 'Occidentalism' and 'Orientalism', terms that are in many ways associated with this topic, are avoided deliberately in the present discussion. Occidentalism has different meaning in today's discourse (e.g. the definitions used in Vlassopoulos 2007 and in Buruma \& Margalit 2005). Orientalism, following Edward Said's defining work (Said 1978) has become a major field of research in its own right, and is difficult to use with any precision on the matters here under discussion. It is, however, interesting to note Said's own prediction which has proved wrong, that 'Nobody is likely to imagine a field symmetrical to Orientalism called Occidentalism.'.

55 'By developing the political, the Greeks became the eye of the needle through which the whole of the world history had to pass before it could arrive at the modern European stage', Meier 2005. 56 Turner 1989; Bernal 1987; Kurke 1999; Hanson 2002; 2004; Meier 2005; Vlassopoulos 2007.

57 Vlassopoulos 2007, 101, 117.

${ }^{58}$ Hornblower argued that Mausolus must rather be considered a proto-Hellenistic ruler than Oriental oligarch $(1982,351-354)$. And the significance of new forms of funerary monuments deriving from the Near East and adopted by the Greeks in the fourth-fifth centuries have been pointed out by Hagemajer Allen 2003 (ref. from Vlassopoulos 2007). Cf. also e.g. Spivey 1996, 191-196 for Lycian influences. 
We are of course aware that the Hecatomnid rulers employed some of the most renowned Eastern Mediterranean artists and architects of the time for their building programmes and iconographic decorations in the capital Halicarnassus. The Hippodamian city-plan was modelled on nearby poleis. The coinage corresponded to weight standards prevalent in the surrounding poleis. But it becomes too easy to regard these as arguments supporting the idea that the ruling family of the satrapy aspired to become 'Greek'. Such an assumption is mainly based on an outdated view of cultures and material expressions as homogeneous, pure, as representative of dominant cultures as ideal, and as one-sided influencers dominating more peripheral and receptive cultures. ${ }^{59}$

In twentieth-century scholarly debate, synoecisms had a strong association with democracy. And, coinage was considered to be part of the democratic institutions and symbols of a synoecized, autonomous polis. The Hecatomnid dynasty in Halicarnassus, on the other hand, was a satrapy under Persian sovereignty. Some twentieth-century historians interpreted Mausolus' ambitions as he held the Greek polis as an ideal, and assumed he wanted to interfere with the nearby poleis, like Cos. This assumption made room for interpretation of the iconography of coinage based on the tension between two contrasting political systems. A precondition for this is that coinage is considered as a political symbol rather than an economic tool for the issuing power. However, there are few if any arguments to support an interpretation of the coinage and its iconography as functioning primarily for propaganda and symbolic purposes - either of an autonomous city-state or of the Carian satrapy.

For most of the twentieth century, coinage of the Greek poleis was subjected to interpretation based on sociological and anthropological theory where the economic

59 A one-sided Greek influence can easily be rejected, e.g. Henry 2013 discusses the local predecessors and influences on the Mausoleum in Halicarnassus, and Konuk 2013 lists several examples on eastern influence in the coinage of both Hecatomnus and Mausolus, cf. the so-called 'griffin-slayer type' of Hecatomnus and 'archertype' of Mausolus (pl. 1, n. 13, and pl. 2, nos. 19 and 20). The nature of the Hecatomnid ruler-cult is also relevant in this context, but it is not possible to explore it fully here. Recent research produces ever new knowledge about the cultural contextualization of the Mausoleum, and the ambitions of the Hecatomnid Royal family. The Hecatomnus monument in Milas has already been mentioned above and joins the ranks of other monuments in Labraunda and Iasos, among others, which contribute to knowledge about the aristocratic ruling cult in Caria. Several studies contribute to a greater understanding of how complex the cult was, e.g. Carstens 2009, 2013a; Henry 2013 and several articles in van Bremen and J.-M. Carbon 2010. Carsten 2013a, 179-180 sums it up like this: 'In the Maussolleion, many facets of the new dynasty were incorporated: the local ancestry, the Persian dresses of the ancestral portraits, the Hellenic motifs, and inspiration from Lykian podium tombs. (---). If the Maussolleion is only perceived as a piece of Greek architecture and sculpture it seems unredeemed. However, placed in a broader Anatolian perspective, it unfolds itself into numerous facets: it was not (only) placed in the city center because Maussollos was the founding father of the new capital, but because it was the foremost sanctuary of the new Karian dynasty. The cult of Maussollos was intended to unite the Karians, and to confirm the Hekatomnids as dynasties.' 
function was overshadowed by social and symbolic content. ${ }^{60}$ The emphasis on a symbolic interpretation caused many to consider coinage in close connection with the establishment of the Greek poleis and the phenomenon of synoecisms. Coinage has been interpreted mainly as a symbol of autonomy and eleutheria, as something like a flag for the newly established democratic Greek city-state. This understanding was adopted by historians, and it became fashionable to link coinage to political and historical events. Thus, coinage and synoecism was automatically connected, which affected the chronologies and linking to historical events of many important city-state coinages. Moses Finley summarized this concept when he stated that coins were 'merely a political symbol, the flag of the autonomous Greek city-state. The resources put into the Greek coinages was economically non-sense'. ${ }^{61}$ When the economic function was removed from the rationale of coinage, mainly symbolic and political functions remained, which opened up for other explanations for why the Coans issued large series of silver coinage. As we have seen above, the interpretation of coins as political symbols for the Hecatomnid intervention in Coan affairs found strong support. ${ }^{62}$

However, the political and/or symbolic interpretation of the fourth-century Coan coinage, and thus its iconography, can safely be strongly modified if not rejected. Arguments proving the existence of the coin issues in question decades before the synoecism demonstrate the missing connection between coinage and synoecism on $\mathrm{Cos}^{63} \mathrm{On}$ the contrary, three significant facts indicate the existence of a political union well before 366. Firstly, the Coans were listed as koioi in the Quota list of the Delian

${ }^{60}$ For criticism and interpretative models, cf. Ingvaldsen (Roland) 2005; see e.g. Malinowski 1921; Mauss 1924; Sahlins 1965; Polanyi 1968; Finley 1973a; Bourdieu 1977; Godelier 1977; Austin \& Vidal-Naquet 1977, 1990; Vernant 1983; Morris 1987; Will 1988; Parry \& Bloch 1989; Kurke 1999. ${ }^{61}$ Finley 1973b, 166-167. See also Austin \& Vidal-Naquet 1977, 58: 'To strike coins with the badge of the city was to proclaim one's political independence'.

${ }^{62}$ Several scholars raised criticism against the political and/or symbolic interpretations of city-state coinage from the 1980s onwards, e.g. Martin 1985; Cohen 1992; Ingvaldsen (Roland) 1994; Gabrielsen 2000; Schaps 2004. Ingvaldsen (Roland) 2006.

${ }^{63}$ Closer examination of the evidence reveals the same pattern elsewhere, e.g. Elis, Mantineia, Tegea, Heraea and Olynthus, see Hansen 1995b, 58-59; for the use of ethnic on Rhodes prior to the synoecism in 408/7, see Meiggs \& Lewis 1968, GHI 7 (Ialysioi); Herodotus 7.153.1 (Lindioi). The three Rhodian cities are described as poleis on several occasions, see Herodotus 1.144; 2.182, 3.47; Thucydides 8.44.2; Diodorus 13.70.2. On Cos at least two communities are mentioned as poleis by ancient authors prior to the synoecism. The 'ancient capital' of Cos, Astypalaea, was called a polis by Strabo (657), and Thucydides (8.41.2) gives us the name of another polis, Cos Meropis. See also Sherwin-White 1978, 44-46. Polis is here defined as habitations with the following five characteristics 1) participation in meetings of the ekeklesia and boule; 2) distinction between the demos and foreigners; 3) political acts by the adult male citizens; 4) expressed ideal that members of the polis would encounter justice; and 5) common place of residence. See Hansen 1998, Appendix II 'Aristotle's Definition of Polis at Pol. 1276b1-2'; Manville 1990, 53. The establishment of a polis by merging several habitations was particularly widespread on the islands, Cos and Rhodes being two typical examples. 
confederacy of which Cos is an attested member state from 451/50 onwards; ${ }^{64}$ secondly, the Coans appear as a single member of the Dorian Pentapolis in the fifth century; ${ }^{65}$ and thirdly, the Coans issued series of coins in the mid-fifth century that

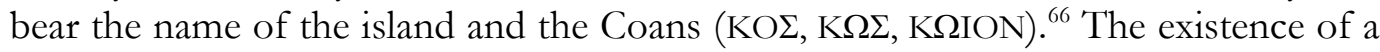
political union on Cos prior to the synoecism is further strengthened by the personal names that occur on coin issues from the 380s onwards. The name on Coan coins has traditionally been interpreted as the eponymous magistrate on Cos, the monarchos. ${ }^{67}$ This theory has previously been rejected by this author, a view that has now gained acceptance and is included in recent studies. ${ }^{68}$ The name, most often called a 'magistrate', represents an appointed or elected official with formal responsibility or practical day-to-day involvement for certain aspects of coining, like organizing the production, control of metal, distribution etc. The appearance of personal names on Coan coins several decades before the synoecism is evidence of co-operation on important matters including responsibility versus foreign states. ${ }^{69}$ What we see is a pattern of organization which was implemented to provide the island with the necessary currency to engage in external interaction and meet internal economic needs. The minting began long before the synoecism and continued long after. There is little

${ }^{64}$ QL IV , 4, 15; ATL IV; Barron 1968, 87.

${ }^{65}$ Herodotus I, 144, 3.

${ }^{66}$ Unfortunately, none of these three indications are conclusive. The Athenians' description of non-synoecized islands in the Quota lists followed no general pattern. In some instances, the name of the island was given, while in others the individual cities were listed. The cities of Rhodes and Carpathus were listed separately, while Ceos, Amorgos and, possibly, Cos were listed with the name of the islands. Similarly, Herodotus does not follow a consistent way of describing islands, non-synoecized settlements or poleis. Cos had only one vote in the Dorian pentapolis, and was listed after the name of the island, in contrast to Rhodes where all three cities are listed as individual poleis. It was common for multi-polate islands to act as a unit towards external powers. This is why the Amorgioi, Keioi, Koioi, Lemnioi, Ikioi etc. are listed in the Quota lists by the name of the respective islands, and not by the contributing poleis within each island. It was common practice to create synteleiai between the poleis on each island in order to co-ordinate the payment of tribute to Athens. Also, the Coan tribute is occasionally divided into two parts, perhaps an indication of the existence of two contributing poleis on the island, see Reger 1997, 454.

${ }^{67}$ The monarchos, an exclusively attested institution on Cos, was the titular head of the state in Hellenistic times. Epigraphic attestation of this magistracy is traced back to approximately 325300 , and the use as eponym not earlier than $c .300-250$. The lack of sources does not, of course, rule out the existence of the monarchos in earlier periods. See Ingvaldsen (Roland) 2004 for a detailed account. For a general account of personal names on Greek coinages, see Furtwängler 1982.

${ }^{68}$ For identification as the monarchos, see Paton \& Hicks 1891, 348; Herzog 1928, 46; PuglieseCarratelli 1969, 333; Sherwin-White 1978, 188; and rejecting the theory: Ingvaldsen (Roland) 1994; Habicht 2000, 323-325; Ingvaldsen (Roland) 2002; Habicht 2004; Ingvaldsen (Roland) 2004; Leschhorn 2006.

${ }^{69} \mathrm{It}$ is worth noting that studies have revealed a political synoecism, or at least a strong political union, on Rhodes preceding the synoecism in 408/7. The existence of a boula and a board of prytaneis acting on behalf of the Rhodians as a unity was attested well before the synoecism, see Gabrielsen 2000, 4-10. 
or no evidence at all for considering the coin issues from the period around 366 primarily as politically charged symbols, either for an autonomous polis or for an oligarch with expansionist ambitions.

The interference of Mausolus on Cos in the years around the synoecisms does not find support in historical sources either. Cos was under shifting alliances in the fifth- and fourth centuries. They were on the Persian side at the battle of Salamis, but one of the contributing cities of the Delian League 451/450. ${ }^{70}$ Spartan dominance is attested in 394. ${ }^{71}$ After the final battle off Cnidus in 394, Cos followed Rhodes in the revolt against Spartan rule. This is probably the period that witnessed the first Coan coinage with Heracles as a motif. ${ }^{72}$ The sources are silent about Cos between the battle of Cnidus and the synoecism in 366, except for a conflict between the Coans and the Persian satrap Hecatomnus during the years 390 and $377 .{ }^{73}$ In the year 366/5, an outbreak of stasis is attested by two ancient sources. ${ }^{74}$ According to the classical writers, this short civil war was the reason behind the foundation of a new capital on the northeast end of the island, the introduction of democratic institutions and the introduction of the large issues of silver coinage from 366 onwards. On the other side of the strait between the mainland and Cos, major changes happened in the aftermath of the satrap Hecatomnus' death in 377/6 and succession by his son Mausolus. ${ }^{75}$ Mausolus' plan was probably to gather the Greek cities along the coast of Asia Minor and the adjacent islands into one small empire. Hecatomnid control was extended and included the islands of Cos and Rhodes. ${ }^{76}$ The year of the synoecism of Halicarnassus is not known. Diodorus provides us with a t.a.q. of $362 .{ }^{77}$ As mentioned above, the Coan synoecism has been interpreted as a part of Mausolus' attempt to establish a 'Carian front', and contact between Cos and the Hecatomnids is attested by the use of Coan building materials in Halicarnassus. However, contact attested by shipments of marble and limestone do not prove political influence. What we do know is that Cos turned against Athens in 357/6, and Mausolus gained control over Cos when democracy was rejected for a limited time. ${ }^{78}$

\footnotetext{
70 ATL IV; Barron 1968: 87. The first appearance of the Coans in the tribute lists in 451/0 does not, however, rule out the possibility of membership before that date. See comments in Buckley 1996: 205 on the reason why some member islands might not figure in the tribute list until 451/0 despite joining the League at an earlier date.

${ }^{71}$ Diodorus XIV, 84, 3-4; Sherwin-White 1978, 38.

${ }^{72}$ Stefanaki 2012, 188, Series IV.

${ }^{73}$ Sherwin-White 1978, 41 and n. 64-65.

${ }^{74}$ Diodorus XV, 76; Strabo 657.

75 See Sherwin-White 1978, 68 and especially note 200 on the satrapy of Mausolus. The standard work on Mausolus and the historical events related to the Hecatomnid dynasty in the mid-fourth century is still Hornblower 1982.

${ }^{76}$ See $C A H$ VI, 226-227 for the events and further references and sources.

77 Diodorus XV 90, 3.

${ }^{78}$ Aristotle, Politics, 1304, b5.
} 
There are, then, few arguments to support the view of coinage as a political symbol on behalf of a synoecized polis, nor is any Hecatomnid intervention on the Coan synoecism supported by historical sources. The coinage was in the name of the Coans as an ethnic group identified by the geographical limitations naturally provided by the island border. The first major Coan coin issues with their renderings of Heracles and Demeter cannot be considered primarily as political symbols of an 'autonomous' or democratic city-state, or of any oligarchic influence on the city. There are simply no arguments left to support the theory that the coinage and its iconography was employed as a medium of political communication on behalf of the Carian satrapy in the fourth century.

We are left with reputable scholars who have constructed and repeated historical narratives without empirical evidence. Perhaps the modern idea of an oligarch's interference in the inner affairs of a small, democratic polis made it tempting to search for confirmation or attestation of this in the archaeological material. Attributing 'portraits' in this way would probably not have been attempted if not for the tension modern scholars have read into the situation of a newly established, small 'Greek' democracy and a dominating oligarchic 'Persian' power nearby. To a certain degree, it is possible to argue that the differences between the democracy in Greek poleis and the city-state cultures in the Near East have been over-emphasized, and have coloured the interpretation of material culture as well as historical narratives for much of the nineteenth- and twentieth centuries: 'The orthodox view that formed the juxtaposition between the world of the Greek polis and the redistributive bureaucratic monarchies of the Orient is grossly misleading' ${ }^{79}$ In this case, it has most probably also clouded the judgement of evidence for 'oligarchic' portraiture on the coinage of a small, 'democratic' Greek polis to prove the intervention of a tyrant on a democratic state.

\section{Concluding remarks}

Archaeologists, art historians and historians will always read various types of general meaning in their data. The example dealt with here illustrates well the importance of self-reflexiveness in the construction of meaning, and of critical approaches when reproducing and injecting meaning into new contexts. The twentieth-century suggestion that the Carian satraps put their portraits on a Greek city-state coinage was the result of uncritical interpretation of material sources. The construction of narrative failed in important steps in the chain of meaning production: fact creation (selective choice of sources), fact assembly (not based on a complete corpus of material), fact retrieval (uncritical use of written [Greek] accounts of Hecatomnid [Oriental] ambitions) and retrospective significance (making 'history' based on [unconscious] 'Eurocentric' biases). ${ }^{80}$

What can be learnt from this is that constructing meaning out of Carian sculptures and Coan coinage in the fourth century demands a broad approach, e.g.

\footnotetext{
79 Vlassopoulos 2007, 117.

${ }^{80}$ Vlassopoulos 2007, 5, referring to Trouillot 1995, 26.
} 
based on considering object as object, object as meaningfully constituted, object as product of situated intentions, and object related to personal experience and contemporary entanglement. ${ }^{81}$ Of particular importance to the example presented here is meaning in relation to the structured content of historical traditions, and socalled 'operational meaning', i.e. meaning that takes into account the specific intentions underlying the actions of people in the past, and the unique, embodied experience of each actor since. It is still a challenging situation that material entanglement has limited penetration into the Ancient history discipline. However, historians alone are not to be blamed since the problem is partly due to the lack of synthesis based on archaeological evidence available to historians. Recent years have witnessed significant progress in archaeological research and approaches that will eventually prove important for renewing historical research as well: the archaeology of space, ritual, social identity, power, memory and exchange, to mention a few. ${ }^{82}$ It goes too far here to bring the extensive discourse on creolization into the discussion in any detail. It is the opinion of this author that entering this discourse in utilizing the concept of creolization will bring nuances and increased understanding to the issues and concepts of mutual cultural influence in the Mediterranean area, and especially so in the areas where cultural encounters in periods were at their most intense, such as Caria during the Hecatomnids. The work of the Danish classical archaeologist Anne Marie Carstens has contributed in this direction, for example. In an article from 2013 she concludes 'Hekatomnid official monuments are hybrid products; they are based on the interplay of different cultural expressions or styles. Hekatomnid iconography is thus Hellenised, Persianised and Karianised. This is the "creol" of Karian culture that allows for an overt display of a unified multiculturalism, a creolisation' ${ }^{83}$

We have witnessed a significant epistemological development from Adolf Fürtwängler's attempt to link major sculptures to the famous artists mentioned in classical Greek texts, via tendencies to consider the homogeneity of the dominant 'Greek' culture as the scale against which everything else is to be measured, to consider transformation and interplay as premises for interpreting material expressions from a multitude of interrelated cultures. A wider approach based on archaeological sources, the new materiality-discourse and material entanglement, rather than historical sources interpreted within a largely 'Eurocentric' framework expressing static constructed dichotomies on the concepts of 'Greek', 'Persian' and 'Egyptian', would soon have proven our 'portraits' of Hecatomnid rulers on coins to have been non-existent, and thus the misleading historical narratives that are still present in scholarly literature could have been avoided.

81 Ingvaldsen (Roland) 2005, 32-34

82 On the importance of archaeological sources and approaches to ancient history research, see Vlassopoulos 2007, 222-223 with references.

${ }^{83}$ Carstens 2013b, 214. See also Pedersen 2013. 
Dr. Håkon Roland

Assoc. Professor

Museum of Cultural History

University of Oslo

hakon.roland@khm.uio.no

\section{Bibliography}
Abbreviations
ATL
The Athenian Tribute Lists (4 vols.), Merritt, B.D, Wade-Gery, H.T., McGregor, M.F. (eds). Princeton 1939-53.
CH Coin Hoards I-IX (1975-2002). London.
$C A H$
Cambridge Ancient History. Cambridge.
CPCActs
Acts of the Copenhagen Polis Centre. Kongelige Danske Videnskabernes Selskab, Historisk-filosofiske Meddelelser.
CPCPapers
Papers from the Copenbagen Polis Centre. Historia Einzelschriften.
IGCH
An Inventory of Greek Coin Hoards, Thompson, M., Mørkholm, O., Kraay, C.M. (eds). New York 1973.
PP
Prosopographia Ptolemaica, Peremans, W. et al. (eds), 1-9. Studia Hellenistica 6, 8, 11-13, 17, 20-21. Louvain 1950-81.
SNG von Aulock
Sylloge Nummorum Graecorum, Deutschland. Sammlung Hans von Aulock, Heft 7: Karien. Berlin, British Academy 1962.

\section{References}

Anderson, A. 1983: 'The culture of the Greek polis: The unified view of Plato and Aristotle', in R.T. Marchese (ed.), Aspects of Graeco-Roman Urbanism. Essays on the Classical City, 42-60. Oxford: BAR.

Ashton, R. 1986: 'Rhodian bronze coinage and the earthquake of 229-226 BC', NC 146: $1-18$. 
Austin, M. M. \& Vidal-Naquet, P. 1977: Economic and Social History of Ancient Greece: An Introduction. Berkeley: University of California Press.

Barron, J. P. 1966: The Silver Coins of Samos. London: Athlone Press.

Barron, J. P. 1968: 'The Fifth century diskoboloi of Kos', in C. M. Kraay \& G. K. Jenkins (eds), Essays in Greek Coinage presented to Stanley Robinson, 75-90. Oxford: Clarendon Press.

Bernal, M. 1987: Black Athena. The Afroasiatic Roots of Classical Civilization. The Fabrication of Ancient Greece 1785-1985, vol. 1. New Brunswick: Rutgers University Press.

Bieber, M. 1955: The Sculpture of the Hellenistic Age. New York: Columbia University Press.

Boardman, J. 1973 (1981): Greek Art, reprinted version. London: Thames \& Hudson.

Bourdieu, P. 1977: Outline of a Theory of Practice. Cambridge: Cambridge University Press.

Buckley, T. 1996: Aspects of Greek history 750-323 BC. A Source-Based Approach. London: Routledge.

Buruma, I \& Margalit, A. 2005: Occidentalism. The West in the Eyes of its Enemies. London: Penguin Books.

Carstens, A. M. 2009: Karia and the Hekatomnids. The Creation of a Dynasty. Oxford: Archeopress.

Carstens, A. M. 2013a: 'Divine Kingship at the City Centre', in O. Henry (ed.), Le mort dans la ville. Pratiques, contextes et impacts des inbumations intra-muros en Anatolie, du début de l'Age du Bronze à l'époque romaine, Istanbul, 14-15 novembre, 2011, 175-182. Istanbul: Institut Francais D'etudes Anatoliennes.

Carstens, A. M. 2013b: 'Karian identity - A game of opportunistic politics or a case of creolisation?’. In Henry (ed.), 209-215.

Cohen, E. E. 1992: Athenian Economy and Society. A Banking Perspective. Princeton University Press: Princeton.

Cook, B. F, Ashmole, B \& Strong, D. 2005: Relief Sculpture of the Mausoleum at Halicarnassus. Oxford: Oxford University Press. 
Finley, M. I. 1973a: Democracy Ancient and Modern. New Brunswick: Rutgers University Press.

Finley, M. I. 1973b: The Ancient Economy. Berkeley \& Los Angeles: University of California Press.

Flensted-Jensen, P \& Hansen, M. H. 1996: “Pseudo-Scylax” Use of the Term Polis', CPCPapers 3: 137-167.

Furtwängler, A. 1982: 'Griechische Vieltypenprägung und Münzbeamten', SNR 65: 524.

Gabrielsen, V. 2000: 'The synoikized polis of Rhodes', in P. Flensted-Jensen, T. Heine Nielsen \& L. Rubinstein (eds), Polis and politics: Studies in ancient Greek bistory presented to Mogens Herman Hansen on his sixtieth birthday, 177-206. Copenhagen: Museum Tusculanum Press.

Godelier, M. 1977: Perspectives in Marxist Anthropology. Cambridge: Cambridge University Press.

Habicht, C. 2000: 'Zur Chronologie der hellenistischen Eponyme von Kos', Chiron 30: 303-332.

Habicht, C. 2004: 'The dating of the Koan monarchoi', BOREAS 28: 61-69.

Hagemajer Allen, K. 2003: 'Becoming the "Other": attitudes and practices at the Attic cemeteries', in C. Dougherty \& L. Kurke (eds), The Cultures within Ancient Greek Culture: Contact, Conflict, Collaboration, 207-236. Cambridge: Cambridge University Press.

Hall, E. 1989: Inventing the Barbarian: Greek Self-Definition through Tragedy. Oxford: Clarendon Press.

Hansen, M. H. 1995a: "The "Autonomous city-state". Ancient fact or modern fiction?', CPCPapers 2: 21-44.

Hansen, M. H. 1995b: 'Boiotian poleis. A test case', CPCActs 2: 13-63.

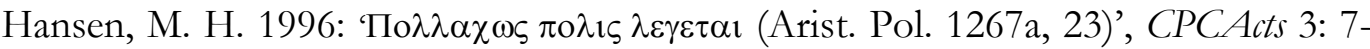
72 .

Hansen, M. H. 1998: Polis and City-State. An Ancient Concept and its Modern Equivalent. Copenhagen: Royal Danish Academy of Sciences and Letters. 
Hanson, V. D. 2002: Why the West Has Won: Carnage and Culture from Salamis to Vietnam. London: Gardners Books.

Hanson, V. D. 2004: Between War and Peace: Lessons from Afghanistan to Iraq. New York: Random House Trade.

Hellström, P. 1993: 'Mausoleet i Halikarnassos', in P. Hellström \& S. U. Sörling (eds), Antikens sju underverk, 61-78. Stockholm: Carlsson Bokförlag.

Henry, O. (ed.) 2013: 4th Century Karia. Defining a Karian identity under the Hekatomnids. Varia Anatolica. Istanbul \& Paris: Institut Francais D'etudes Anatoliennes-Georges Dumézil.

Henry, O. 2013: 'A tribute to the Ionian renaissance'. In Henry (ed.), 81-90.

Herzog, R. 1928: Heilige Gesetz, von Cos. Berlin: Walter de Gruyter.

Hill, G. F. 1923: 'Some coins of Southern Asia Minor', in W.H. Buckler \& W.M. Calder (eds), Anatolian Studies presented to Sir William Mitchell Ramsay, 207-235. London \& New York: Manchester University Press.

Hoepfner, W. 1996: 'Zum Maussolleion von Halikarnassos', AA 1: 95-114.

Hoepfner, W. 2013: Halikarnassos und das Maussolleion. Die modernste Stadtanlage und der als Weltwunder gefeierte Grabtempel des karischen Königs Maussollos. Darmstadt \& Mainz: Philipp von Zabern.

Höghammar, K. 1993: Sculpture and Society. A study of the connection between the free-standing sculpture and society on Cos in the Hellenistic and Augustean periods. Stockholm: Almqvist \& Wiksell International.

Horden, P \& Purcell, N. 2000: The Corrupting Sea. A Study of Mediterranean History. Oxford: Wiley-Blackwell.

Hornblower, S. 1982: Mausolus. Oxford: Clarendon Press.

Ingvaldsen (Roland), H. 1994: 'Utmyntningen på Kos, ca. 366-190 f.Kr', unpublished MA-thesis, University of Oslo.

Ingvaldsen (Roland), H. 2002: COS - Coinage and Society. The chronology and function of a city-state coinage in the Classical and Hellenistic period, c.390 - c.170 B.C., PhD diss., University of Oslo. 
Ingvaldsen (Roland), H. 2004: 'The Function and Meaning of Personal Names on the Coan Coinage in the Classical and Early Hellenistic Period', in K. Höghammar (ed.), The Hellenistic Polis of Kos: State, Economy and Cultures, 89-98. Uppsala University.

Ingvaldsen (Roland), H. 2005: 'Mellom objekt og symbol. Kontekstbaserte tolkningsteorier for mynters oppkomst og funksjon fra antikken til vår tid', Meta 3: 21 36.

Ingvaldsen (Roland), H. 2006: 'The Foundation of the Coan Polis in 366 B.C. Aspects on Synoecism and Coinage', Obolos 8: 79-86.

Ingvaldsen (Roland), H. 2011: 'The island of Hippokrates, silver coins and a portrait myth', in N.L. Wright (ed.), Coins from Asia Minor and the East, 17-23. Sydney: Australian Centre for Ancient Numismatic Studies.

Isik, G. 2019: Die Wandmalereien in der Grabkammer des Hekatomneions. Beobachtungen zu Figurentypen zur Komposition, Ikonographie und zum Stil. Bonn: Habelt Verlag.

Jenkins, I. 2006: Greek Architecture and its Sculpture. Cambridge: Harvard University Press.

Jenkins, I. 2010: 'The Mausolea of Halicarnassus', in F.C. Macfarlane \& C. Morgan (eds), Exploring Ancient Sculpture: Essays in Honour of Geoffrey W aywell, 121-135. London: University of London.

Jeppesen, K. 1958: Paradeigmata. Aarhus: Aarhus University Press.

Jeppesen, K. 1998: 'Das Maussolleion von Halikarnass. Forschungsbericht 1997', PoDIA 2: 161-231.

Jeppesen, K. 2002: The Superstructure. A comparative analysis of the architectural, sculptural, and literary evidence. Aarhus: Aarhus University Press.

Kabus-Preisshofen, R. 1989: Die Hellenistische Plastik der Insel Kos. Berlin: Mann Verlag.

Konuk, K. 1998: The Coinage of the Hecatomnids of Caria, PhD diss., Oxford University.

Konuk, K. 2013: 'Coinage and Identities under the Hekatomnids'. In Henry (ed.), 101 121.

Kurke, L. 1999: Coins, Bodies, Games, and Gold. The Politics of Meaning in Archaic Greece. Princeton: Princeton University Press. 
Leschhorn, W. 2006: 'Die antiken Münzen von Kos. Aufschriften und Beamtennamen', Obolos 8: 87-104.

Luttrell, A. 1986: The Maussolleion at Halicarnassus: reports of the Danish Archaeological Expedition to Bodrum. The written sources and their Archaeological background, vol. 2. Højbjerg: Jutland Archaeological Society.

Malinowski, B. 1921: 'The primitive economies of the Trobriand islanders', Int. Econ. J. 31: 1-16.

Manville, P.B. 1990: The Origins of Citizenship in Ancient Athens. Princeton: Princeton University Press.

Martin, T. 1985: Sovereignty and Coinage in Classical Greece. Princeton: Princeton University Press.

Mauss, M. 1924: 'Essai sur le don. Forme et raison de l'échange dans le sociétés archaïques', Sociologie et anthropologie 1: 143-279.

Meiggs, R \& Lewis, D. M. 1968: A selection of Greek inscriptions (no.45) to the end of the fifth century. Oxford: Oxford University Press.

Meier, C. 2005: From Athens to Auschwitz: The Uses of History. Cambridge: Harvard University Press.

Morris, I. 1987: Burial and Ancient Society: The Rise of the Greek City-State. Cambridge: Cambridge University Press.

Mørkholm, O \& Zahle, J. 1976: 'The Coinages of the Lycian Dynasts Kheriga, Kherei and Erbbina. A numismatic and Archaeological Study', ActaArch 47: 57-113.

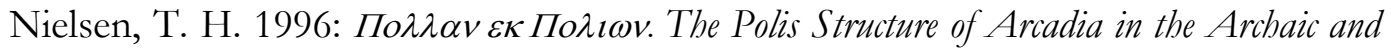
Classical Periods, PhD diss., University of Copenhagen.

Parry, J \& Bloch, M. 1989: Money and the Morality of Change. Cambridge: Cambridge University Press.

Paton, W. R \& Hicks, E. L. 1891: The inscriptions of Cos. Oxford: Clarendon Press.

Pedersen, P. 1989: 'Some general trends in architectural layout of $4^{\text {th }}$ c. Caria', BOREAS 17: 9-15. 
Pedersen, P. 2013: 'The $4^{\text {th }}$ century BC 'Ionian Renaissance' and Karian Identity'. In Henry (ed.), 33-64.

Pedersen, P. 2015: 'On the planning of the Maussoleion at Halikarnassos', in S. Faust, M. Seifert \& L. Ziemer (eds), Antike. Architektur. Geschichte. Festschrift für Inge Nielsen zum 65. Geburtstag, 153-166. Aachen: Shaker Verlag.

Polanyi, K. 1968: Primitive, Archaic and Modern Economies: Essays of Karl Polanyi, edited by G. Dalton. New York: Anchor Books.

Prag, J. \& Neave. R. 1994: 'Who is the 'Carian Princess?', in J. Isager \& P. Pedersen (eds), Hecatomnid Caria and the Ionian Renaissance, 97-109. Odense: Odense University Press.

Prag, J. \& Neave, R. 2010: 'Sibling Semblance: Mausolus and his sisters', in F. C. Macfarlane \& C. Morgan (eds), Exploring Ancient Sculpture: Essays in Honour of Geoffrey Waywell, 109-120. London: University of London.

Pugliese-Carratelli, G. 1969: 'Monarchos Coo e stephanophoros Calimno', PP 24: 374376.

Reger, G. 1997: 'Island with one polis versus islands with several poleis', CPCActs 4: 450-492.

Richter, G. M. 1965: Portraits of the Greeks, vol. 2. London: Phaidon Press.

Rumscheid, F. 2010: 'Mausollos and the 'Uzun Yuva' in Mylasa: an unfinished ProtoMaussolleion at the heart of a new urban centre?', in R. van Bremen \& J.-M. Carbon (eds), Hellenistic Karia, 69-121. Pessac: Ausonius Éditions.

Sahlins, M. 1965: 'On the sociology of primitive exchange', in M. Banton (ed.), The relevance of models for social anthropology, 139-227. London \& New York: Routledge.

Said, E. 1978: Orientalism. New York: Pantheon Books.

Schaps, D. 2004: The Invention of Coinage and the Monetization of Ancient Greece. Ann Arbor: University of Michigan Press.

Sherwin-White, S. M. 1978: Ancient Cos. An historical study from the Dorian settlement to the Imperial period. Göttingen: Vandenhoeck \& Ruprecht.

Six, J. P. 1899: ‘Maussollos Fürst von Mylasa, Satrap von Karien’, RM 14: 81-83. 
Spivey, N. 1996: Understanding Greek Sculpture. Ancient Meanings, Modern Readings. London: Thames \& Hudson.

Stampolidis, N. C. 1989: 'On the provenance of the marble of the Mausolean Amazonomachia frieze’, BOREAS 17: 45-51.

Stefanaki, V. 2012: Cos I. Nomismata - Nomismatiki Aigaiou. Athens: Archaiologiko Instituto Aigaiakon Spoudon.

Svoronos, J. 1904-1908: Ta Nomismata tou Kratous ton Ptolemaion, 4 vols. Athens: Typois P. Sakellariou.

Trouillot, M.-R. 1995: Silencing the Past: Power and the Production of History. Boston: Beacon Press.

Turner, F. M. 1989: 'The Greek Heritage in Victorian Britain', in G. W. Clarke (ed.), Rediscovering Hellenism: The Hellenic Inheritance and the English Imagination, 61-82. London \& New York: Cambridge University Press.

Venturi, F. 1963: ‘Oriental despotism', J. Hist. Ideas 24: 133-142.

Verdiani, G, Frascari, A \& Giraudeau, S. 2017: 'The Halicarnassus Mausoleum, a Digital Rereading. Step 1: The Statues at the British Museum', in W. Börner \& S. Uhlirz (eds), Proceedings of the 22nd International Conference on Cultural Heritage and New Technologies. Vienna: Museen der Stadt Wien - Stadtarchäologie. Available from URL: https://www.researchgate.net/publication/332864787_The_Halicarnassus_Mausole um_a_Digital_Rereading_Step_1_The_Statues_at_the_British_Museum [accessed 13 November 2020]

Vernant, J.-P. 1983: Myth and Thought among the Greeks. London \& Boston: Routledge.

Vidal-Naquet, P. 1990: 'Karl Wittfogel et la notion de mode de production asiatique: note liminaire', in P. Vidal-Naquet (ed.), La Démocratie grecque vue d'ailleurs: essais d'historiographie ancienne et modern, 277-316. Paris: Flammarion.

Vlassopoulos, K. 2007: Unthinking the Greek Polis. Ancient Greek History beyond Eurocentrism. Cambridge: Cambridge University Press.

Waywell, G. F. 1978: The Free-standing Sculptures of the Mausoleum at Halicarnassus in the British Museum: a catalogue. London: British Museum.

Weber, H. 1892: 'On some unpublished or rare coins in my collection', NC 1892: 185208. 
Will, E. 1988: 'Review of T. R. Martin Sovereignty and Coinage in Classical Greece', Echos du monde classique 32: 417-420. 